\title{
Feasibility of Monitoring the Strength of HTGR Core Support Graphite--Part III
}

NUREG/CR--2929

DE83 007941

Manuscript Completed: September 1982

Date Published: February 1983

Prepared by

W. C. Morgan, T. J. Davis, M. T. Thomas

Pacific Northwest Laboratory

Richland, WA 99352

\author{
Prepared for \\ Division of Accident Evaluation \\ Office of Nuclear Regulatory Research \\ U.S. Nuclear Regulatory Commission \\ Washington, D.C. 20555 \\ NRC FIN B2101-2
}

\section{DISCLAIMER}

\begin{abstract}
This report was prepared as an account of work sponsored by an agency of the United States Government. Neither the United States Government nor any agency thereof, nor any of their employees, makes any warranty, express or implied, or assumes any legal liability or responsibility for the accuracy, completeness, or usefulness of any information, apparatus, product, or process disclosed, or represents that its use would not infringe privately owned rights. Reference herein to any specific commercial product, process, or service by trade name, trademark, manufacturer, or otherwise does not necessarily constitute or imply its endorsement, recommendation, or favoring by the United States Government or any agency thereof. The views and opinions of authors expressed herein do not necessarily state or reflect those of the United States Government or any agency thereof.
\end{abstract}




\section{DISCLAIMER}

This report was prepared as an account of work sponsored by an agency of the United States Government. Neither the United States Government nor any agency Thereof, nor any of their employees, makes any warranty, express or implied, or assumes any legal liability or responsibility for the accuracy, completeness, or usefulness of any information, apparatus, product, or process disclosed, or represents that its use would not infringe privately owned rights. Reference herein to any specific commercial product, process, or service by trade name, trademark, manufacturer, or otherwise does not necessarily constitute or imply its endorsement, recommendation, or favoring by the United States Government or any agency thereof. The views and opinions of authors expressed herein do not necessarily state or reflect those of the United States Government or any agency thereof. 


\section{DISCLAIMER}

Portions of this document may be illegible in electronic image products. Images are produced from the best available original document. 
Methods are being developed to monitor, in-situ, the strength changes of graphite core-support components in a High-Temperature Gas-Cooled Reactor (HTGR). The results reported herein pertain to the development of techniques for monitoring the core-support blocks; the PGX graphite used in these studies is the grade used for the core-support blockes of the Fort St. Vrain HTGR, and is coarser-grained than the grades used in our previous investigations. The through-transmission ultrasonic velocity technique, developed for monitoring strength of the core-support posts, is not suitable for use on the core-support blocks. Eddy-current and ultrasonic backscattering techniques have been shown to be capable of measuring the density-depth profile in oxidized PGX and, combined with a correlation of strength versus density, could yield an estimate of the strength-depth profile of in-service HTGR core support blocks. Correlations of strength versus density and other properties, and progress on the development of the eddy-current and ultrasonic backscattering techniques are reported herein. 


\section{PREFACE}

A review (BNWL-B-359), funded by the U.S. Atomic Energy Commission, established the theoretical feasibility of non-destructively monitoring the strength, in situ, of the core-support components of a High Temperature GasCooled Reactor (HTGR). This document is the third of a series reporting the experimental verification of feasibility and refinement of the techniques for in-service monitoring. The work reported in Part I (BNWL-2239), sponsored by the U.S. Energy Research and Development Administration, established a direct correlation between the compressive strength of oxidized graphite cylinders and the velocity of ultrasonic waves transmitted diametrally through the cylinders; for this geometry, with this grade of graphite, the correlation is practically independent of tine oxidation-depth profile. The work reported in Part II (NUREG/CR-0995); PNL-3126), sponsored by the U.S. Nuclear Regulatory Commission, extended the investigation to other grades of graphite, prototypic of those which might be used for the core-support posts in an advanced HTGR; it also established the need for obtaining density-depth profiles for components of non-cylinderical geometry, and for some grades of graphite even if the geometry is cylinderical. This report (Part II) extends the investigation to non-destructive techniques for measuring the density-depth profile in a graphite grade, prototypic of HTGR core-support blocks. 


\section{CONTENTS}

SUMMARY

PREFACE

LIST OF SYMBOLS AND UNITS

INTRODUCTION

CONCLUSIONS

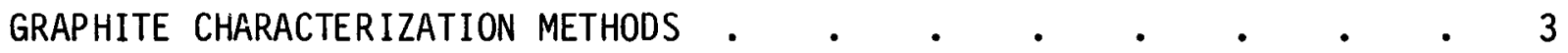

THROUGH-TRANSMISSION ULTRASONIC VELOCITY TESTS $\quad$ • $\quad$ • $\quad$ • 3

ULTRASONIC SURFACE WAVE VELOCITIES • • • • • • • • 4 . 4

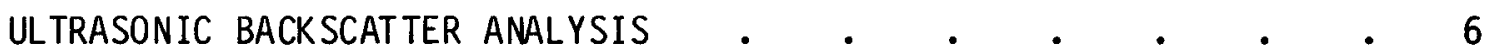

EDDY-CURRENT MEASUREMENTS

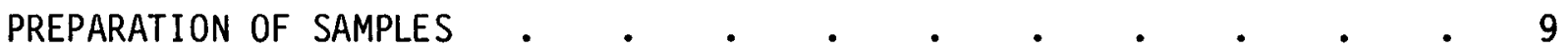

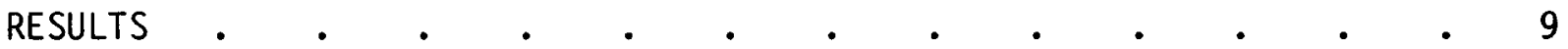

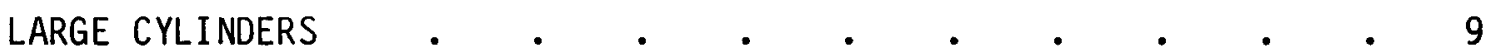

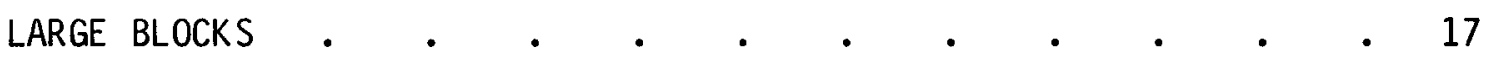

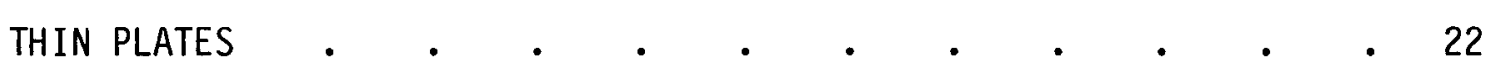

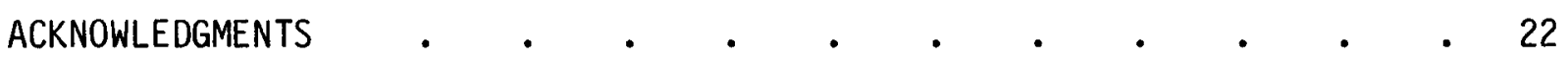

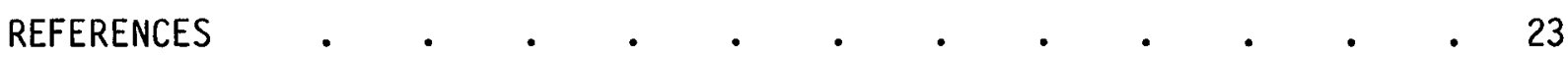

APPENDIX A--SAMPLING SCHEMES AND PREPARATION OF SAMPLES $\quad$ • • $\quad$ - A-1

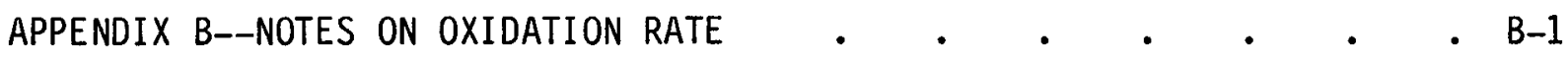




\section{FIGURES}

1 Ultrasonic Velocity of the Longitudinal Wave . . . . 3

2 Ultrasonic Velocity of the Shear Wave . . . . . . 4

3 Ultrasonic Surface Wave Apparatus • • • • • • 5

4 Eddy-Current Probe Used for Measuring Graphite Properties . $\quad 7$

5 Close-Up of the Eddy-Current Probe Shown in Figure 4 . ${ }^{2} \quad$. 8

6 Sectioned Sample of Oxidized PGX Graphite . . . . . 15

7 Density Versus 0xidation Depth for a 3.0-in. Diameter Sample . 16

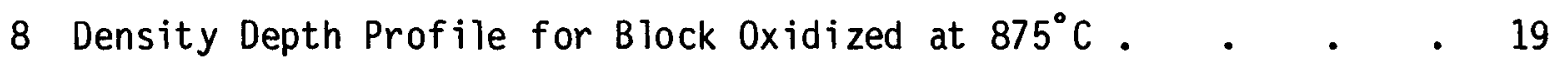

9 Density Depth Profile for Block Oxidized at $925^{\circ} \mathrm{C}$. • • 20

10 Density Depth Profile for Block 0xidized at $1025^{\circ} \mathrm{C}$. . 21

A.1 Perspective View of the Log Section . . . . . . A-1

A.2 Sampling Scheme of Section A • • • • • • • • A-2

A.3 Sampling Scheme of Section B . . . . . . . . A-3

B.1 Weight Loss as a Function of Time-at-Temperature . • . . B-2

B.2 Arrhenius Plot for PGX Blocks . . . . . . . . B-4 
TABLES

1 Properties of Silicone Rubbers Selected for In-Service Ultrasonic Couplants

2 Property Measurements on Unoxidized PGX Cylinders .

3 Pre-0xidation Measurements on PGX Cylinders.

4 Property Measurements on Oxidized PGX Cylinders

5 Rank Correlation Tests on PGX Cylinders.

6 Calculated Compressive Strengths

7 Elemental Composition of Graphite Ash

8 Data on Oxidation of PGX Blocks

A.1 Notes on Sample Preparation

B.1 Calculation of Rate Constants .

vii 


\section{LIST OF SYMBOLS AND UNITS}

$E=$ Elastic Moduli ( $E_{e}=$ Young's Modulus, $E_{s}=$ Shear Modulus) in gigapascals $\left(1 \mathrm{GP}_{3}=1.4504 \times 10^{5} \mathrm{psi}\right)$.

$\rho=$ Density $_{3}\left(\rho_{0}=\right.$ unoxjdized density) in megagrams per cubic meter $\left(1 \mathrm{Mg} / \mathrm{m}^{3}=1 \mathrm{gm} / \mathrm{cm}^{3}\right)$.

$\mathrm{S}=$ Compressive Strength ( $\mathrm{S}_{0}=$ unoxidized strength) in megapascals ( $1 \mathrm{MPa}$ $=145.04$ psi).

$\sigma=$ Posisson's ratio.

$V=$ Ultrasonic velocity $\left(V_{\ell}=\right.$ velocity of the longitudinal wave, $V_{S}=$ velocity of the shear wave) in meters per second

$(1 \mathrm{~m} / \mathrm{s}=3.2808 \mathrm{ft} / \mathrm{sec})$. 


\section{INTRODUCTION}

The underlying principles and basic design of the High-Temperature GasCooled Reactor (HTGR) have been discussed by Fortescue et al. (1960). Walker and Johnson (1969) and Dahlberg et al. (1969) give a more detailed description of the Fort St. Vrain HTGR (FSVR). The FSVR core is composed of vertical stacks of hexagonal graphite blocks, which serve both as neutron moderator and as containment for the fuel. The columns of fueled blocks rest on graphite core support blocks. The support blocks are, in turn, supported on graphite posts. The helium exits from the core through channels in the core support blocks and circulates between the core support posts on its way to the heat exchangers.

Provision is made in the design to continuously purify a fraction of the circulating coolant, so as to remove any oxidizing impurity gases. Such gases can be introduced during normal refueling or maintenance operations from an ingress of air or water and from other sources. During normal operations the concentrations of the oxidizing impurity gases, primarily water vapor and carbon dioxide, are maintained at a very low (a few parts per million) concentration; however, certain abnormal conditions, such as failure of a heat-exchanger tube, can introduce much larger concentrations of reactive gases.

Data on the chemical impurities in the coolant gas during the start-up of the FSVR have been reported by Montgomery and Burnette $(1976,1977)$, Montgomery and Baldwin (1977), and Baldwin and Wolfer (1978). These data and similar data from other graphite-moderated gas-cooled High-Temperature Reactors (HTR), such as Dragon and Peach Bottom, have shown that the gas compositions cannot be accurately predicted (Carlyle and Kinsey 1969; Chapman 1970; Burnette et al. 1971). More importantly, however, the effects of the oxidizing gases on the core support structure cannot be accurately predicted from current knowledge.

It is well known that the strength of graphite is rapidly reduced as a result of oxidation. It is also well known that this reduction in strength can be correlated with changes in density and changes in the elastic modulii. In previous investigations, Morgan and Becker $(1977,1979)$ have shown that the changes in strength $c$ an be monitored by measuring the velocity at which an ultrasonic wave travels through the graphite. From theoretical considerations (Morgan and Becker 1974), one can expect the strength (S) to be related to the ultrasonic velocity (V) by an equation of the form:

$$
S \sim K V^{\alpha}
$$

where $K$ is nearly constant over a wide range of densities, and a equals approximately 2.0. Morgan and Becker (1979) have tested the relationship shown in Equation 1 by oxidizing samples of four grades of fine-grained graphites, typical of materials which might be used for HTGR core support posts, in a mixture of $\mathrm{CO}_{2}$ and $\mathrm{CO}$. A good correlation was obtained for each of the graphites, 
including Union Carbide(a) grade ATJ which was used for the core support posts in FSVR. (b) However, the results also indicated that for most applications one would need to measure the oxidation profile as a function of depth into the graph ite.

The work reported herein extends the investigation to Union Carbide grade PGX, which was used for the core support blocks in FSVR, (b) and to the investigation of other nondestructive testing techniques for obtaining the oxidation profile.

\section{CONCLUSIONS}

- Both the complicated geometry of the HTGR core-support blocks and the rapid attenuation of Ultrasonic signals in oxidized PGX graphite severely $1 \mathrm{imit}$ the usefulness of ultrasonic velocity techniques for in-service monitoring the core-support blocks.

- A very good correlation between compressive strength and density was obtained for oxidized PGX graphite, similar to the correlations obtained previously with the finer-grained graphites.

- Eddy-current techniques can be used to obtain the density profile near the surface of the blocks and, if the oxidation profile is a continuous analytical function of depth from the surface, this density profile could be extrapolated to obtain a measure of the strength-depth profile in the blocks.

- Under some conditions, the near-surface profile is not indicative of the profile at greater depth. In fact, under some conditions, the oxidation rates at some distance into the block can exceed the rate near the surface.

- Ultrasonic backscattering techniques can be used to obtain the density profile at greater depth and, thus, provide a more reliable estimate of the strength-depth profile.

- Work is continuing to develop both the eddy-current and ultrasonic backscattering techniques to the state where they can be applied to in-service monitoring of the strength changes of HTGR core-support blocks.

(a) Union Carbide Corporation, New York, NY 10017.

(b) "Fort St. Vrain Nuclear Generating Station", Public Service of Colorado, Docket 50267 . 
GRAPHITE CHARACTERIZATION METHODS

Four nondestructive evaluation methods have been, or are currently being, evaluated for their ability to assess graphite oxidation. These are ultrasonic velocity of both the shear- and longitudinal-waves, ultrasonic surface-wave velocities, ultrasonic backscatter analysis, and electrical conductance from eddy-current measurements. A description of each method follows.

\section{THROUGH-TRANSMISSION ULTRASONIC VELOCITIES}

All work on through transmission ultrasonic velocity tests was conducted using apparatus described in an earlier report (Morgan and Becker 1979). This device employed several transmitter-receiver pairs to measure the velocity of sound passing through the graphite cylinders as shown in Figures 1 and 2 . Good correlation of sonic velocity with bulk oxidation has been achieved in various grades of graphite. However, emphasis on use of this technique has decreased for two major reasons:

1. Locating a pair of transmitter-receiver sensors at meaningful positions in the Ft. St. Vrain Core Support Block and accurately gaging the physical distance between them for velocity measurements is not a practical option. These limitations are due to the support block geometry and the capability of the fuel handling machine.

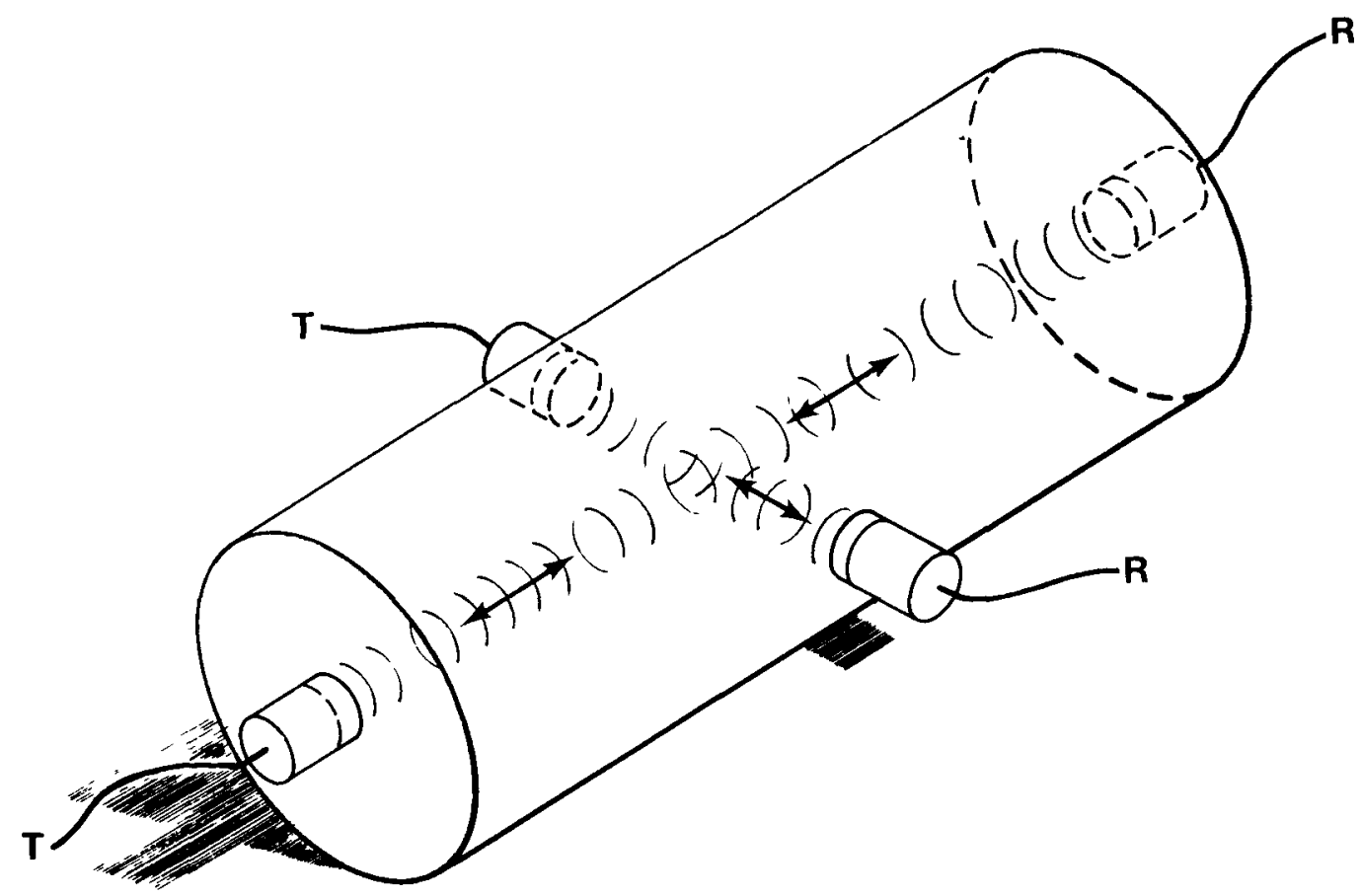

FIGURE 1. Ultrasonic Velocity of the Longitudinal Wave $(T=$ transmitter, $R=$ receiver $)$ 


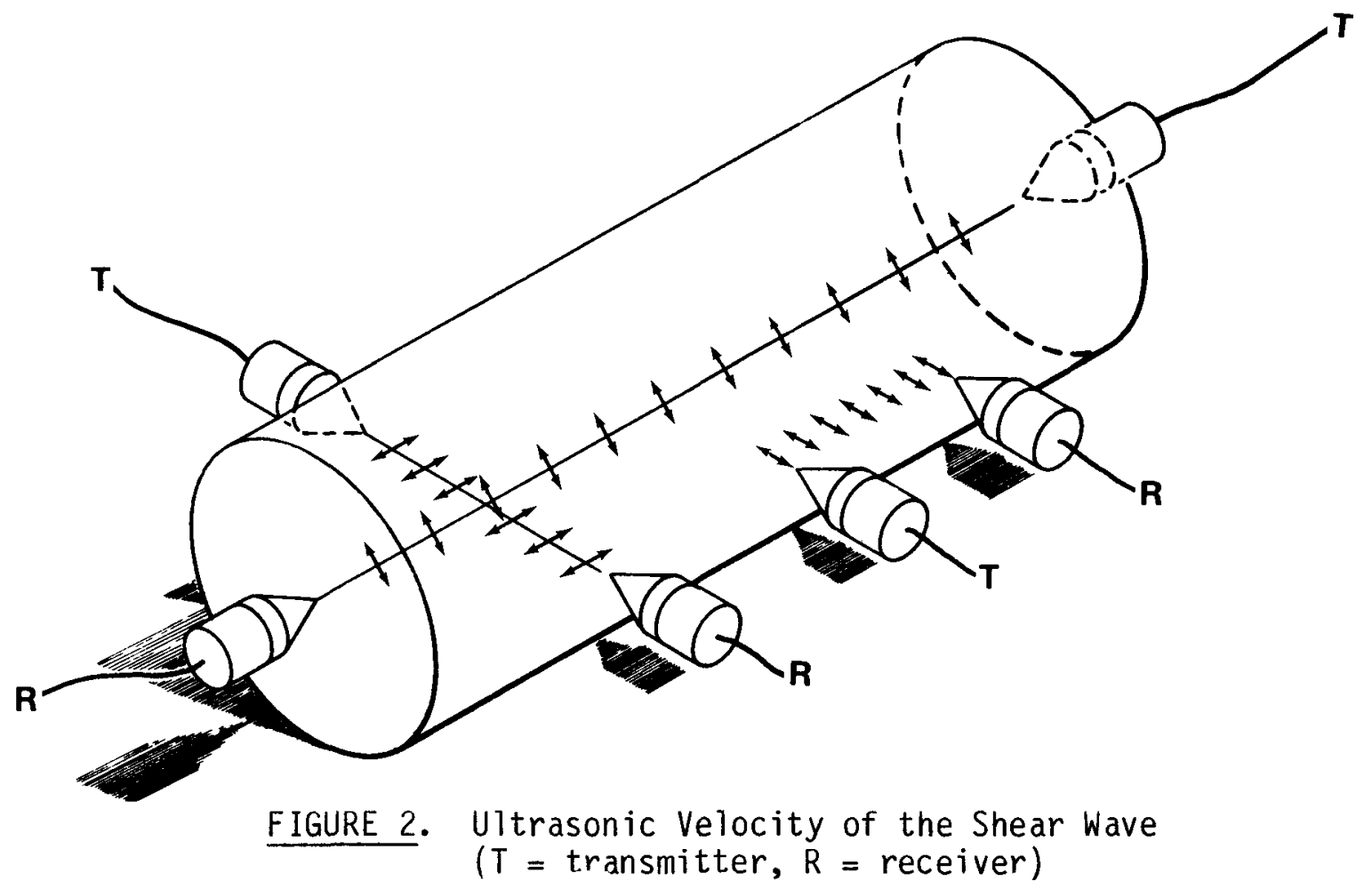

2. Ultrasonic coupling between sensors and the graphite poses a technical problem of some difficulty for field applications. If a very thin plastic couplic member such as those used for lab work is employed, a substantial force must be exerted on the sensor. This poses a risk of fracturing oxidized or reduced strength graphite as evidenced by our laboratory work. A second coupling option is the use of RTV ${ }^{\circledR}$ or silicone elastomer products. Low coupling forces may be used but the velocity measurements can be subject to large error due to the flexibility of these products. The length of the coupling path will vary as a function of the applied force, resulting in the introduction of error to the velocity measurements.

\section{ULTRASONIC SURFACE WAVE VELOCITIES}

An evaluation of surface or Raleigh wave testing was conducted to determine the applicability for profiling near-surface oxidation. The intent was to use several test frequencies to obtain velocity data from different depths of the material. Our findings are as follows:

1. Surface wave velocity is dependent on the degree of oxidation.

2. Graphite oxidized beyond mild weight loss levels (1 to $3 \%$ ) will not sustain surface wave propagation.

(B) Registered Trademark of General Electric Company. 
These findings lead to the conclusion that, although the technique is useful at very low oxidation levels, surface wave testing is not a viable technique for quantizing the degree of graphite oxidation to be expected in an HTGR.

The apparatus used for this evaluation is shown in Figure 3. A large peizoelectric transmitting transducer is angulated to the shear critical angle and is excited with a tone burst. Test frequencies ranging from 100 to $800 \mathrm{kHz}$ were used for the evaluation. Ultrasonic coupling was provided by coupling members fabricated from RTV 118 silicone. A pair of broadband receiving transducers were placed into the surface wave beam at a one-inch separation, and the difference in arrival time of the surface energy was used to calculate surface wave velocity.

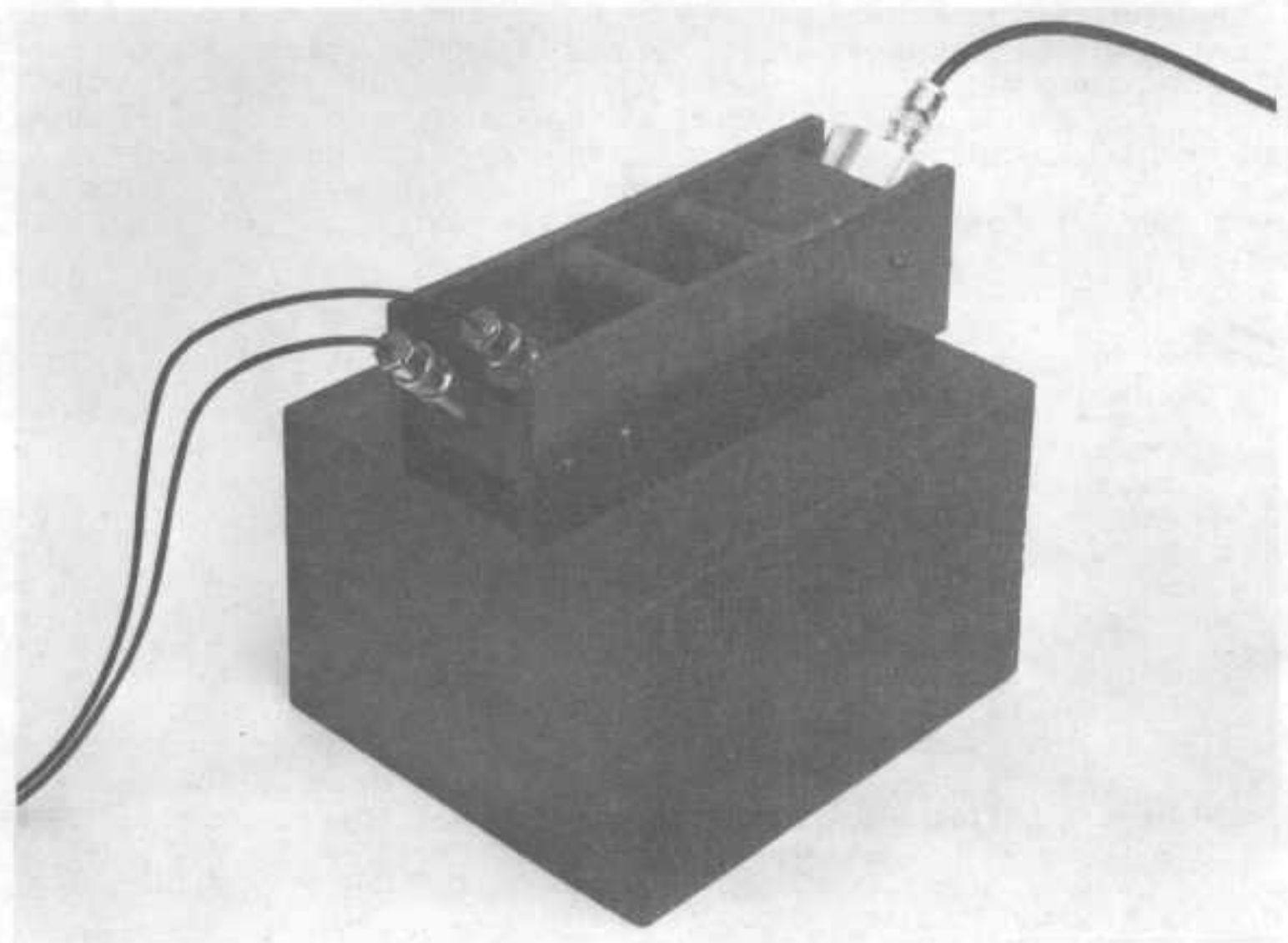

FIGURE 3. UTtrasonic Surface Wave Apparatus 


\section{ULTRASONIC BACKSCATTER ANALYSIS}

Work has been initiated on the application of ultrasonic backscatter methods to the characterization of graphite. Backscatter testing (Goebbels 1980) has been used with high success in other materials for: 1) distinguishing small ultrasonic reflectors from grain boundary scattering noise, 2) measuring grain size, and 3) detecting regions of inhomogenuities such as porosity, inclusions and microcracks. The technique draws its success from statistical separation of desired signals from noise in the received pulse-echo waveform. This is performed by spatial waveform averaging, i.e., summation of waveforms obtained after making small increments in sensor position. Signal averaging with changes in drive frequency or sensor angle also produce good results.

Present indications are that the technique shows promise for detecting and/or quantizing both near-surface and deep oxidation. Work has been completed on determining a suitable couplant for in-service inspection. The ultrasonic properties of a variety of silicone elastomers and rubbers were evaluated and two high-temperature products were selected for future use. These are General Electric RTV $31^{\circledR}$ silicone rubber and Dow Corning $3120^{\circledR}$ silicone rubber. The utrasonic properties we measured in these products are listed in Table 1 .

TABLE 1. Properties of Silicone Rubbers Selected for In-Service Ultrasonic Couplants

\begin{tabular}{|c|c|c|}
\hline Product & $\begin{array}{c}\text { Attenuation } \\
\text { at } 2.25 \mathrm{MHz}, \\
\mathrm{dB} / \mathrm{mm}\end{array}$ & $\begin{array}{c}\text { Ultrasonic } \\
\text { Velocity, } \\
\text { m/s }\end{array}$ \\
\hline RTV31 & 2.25 & 910 \\
\hline 3120 & 1.78 & 910 \\
\hline
\end{tabular}

Current work is centered upon preparing to correlate backscatter data with actual oxidation in graphite. Waveforms will be digitized and averaged through the use of a Biomation transient digitizer and a DEC 1103 minicomputer system.

\section{EDDY-CURRENT MEASUREMENTS}

A strong correlation has been established between eddy-current data and graphite density and/or oxidation and substantial work has been conducted to optimize methods for profiling near-surface oxidation. The electrical conductivity of the graphite is detected by the eddy-current method and used as a measure of oxialion. The depth of penetration can be controlled by selection of test frequency, permitting profile or oxidation versus depth, to be determined through use of several test frequencies. The technique should be useful up to a depth of 3.8 to $5.0 \mathrm{~mm}$, depending on the size of the search coil used. 
The present status of this work is that a computer algorithm is under development for estimating the oxidation profile as a function of eddy-current data.

Illustrations of one of the probes used for obtaining laboratory data are shown in Figures 4 and 5 . This probe consists of 15 turns of wire on each end of a 19-mim diameter nylon rod. One coil is used for sensing graphite properties and the other is used as a reference coil for temperature compensation. The probe was interfaced to a conventional impedance-plane eddy-current instrument. This instrument generates outputs corresponding to resistance and reactance parameters of the search coil. These parameters are in part a function of the electromagnetic loading of the coil caused by induced eddy currents in the graphite. Consequently, the parameters may be analyzed to interpret electromagnetic properties of the graphite, e.g., its electrical conductivity.

A variety of measurements have been acquired using thin plates of graphite which have been oxidized to various degrees. This permits various oxidation profiles to be simulated by the plate stacking order. Test frequencies of $4 \mathrm{MHz}, 1 \mathrm{MHz}$ and $100 \mathrm{kHz}$ were selected for the data acquisition

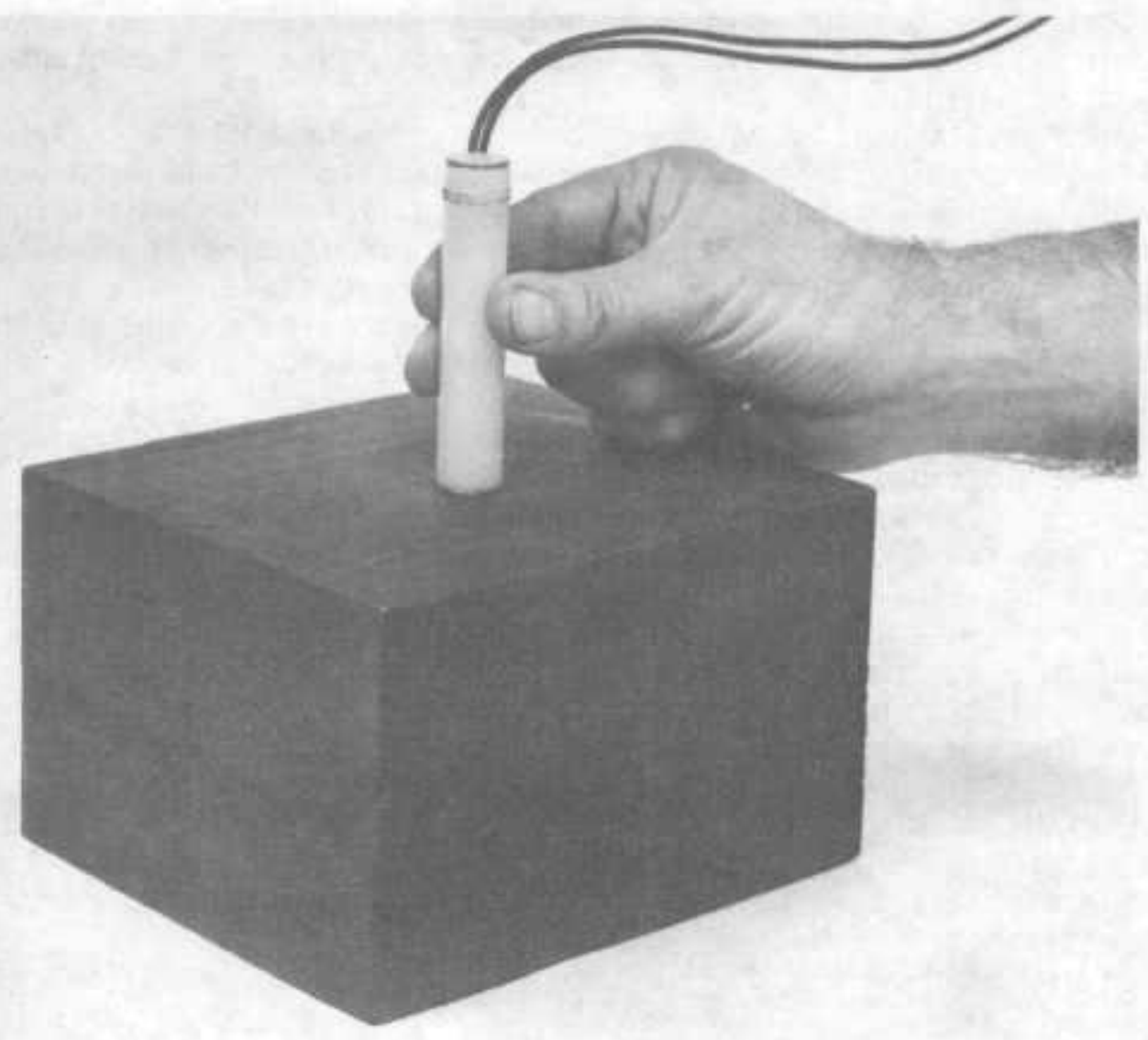

FIGURE 4. Eddy-Current Probe Used for Measuring Graphite Properties 


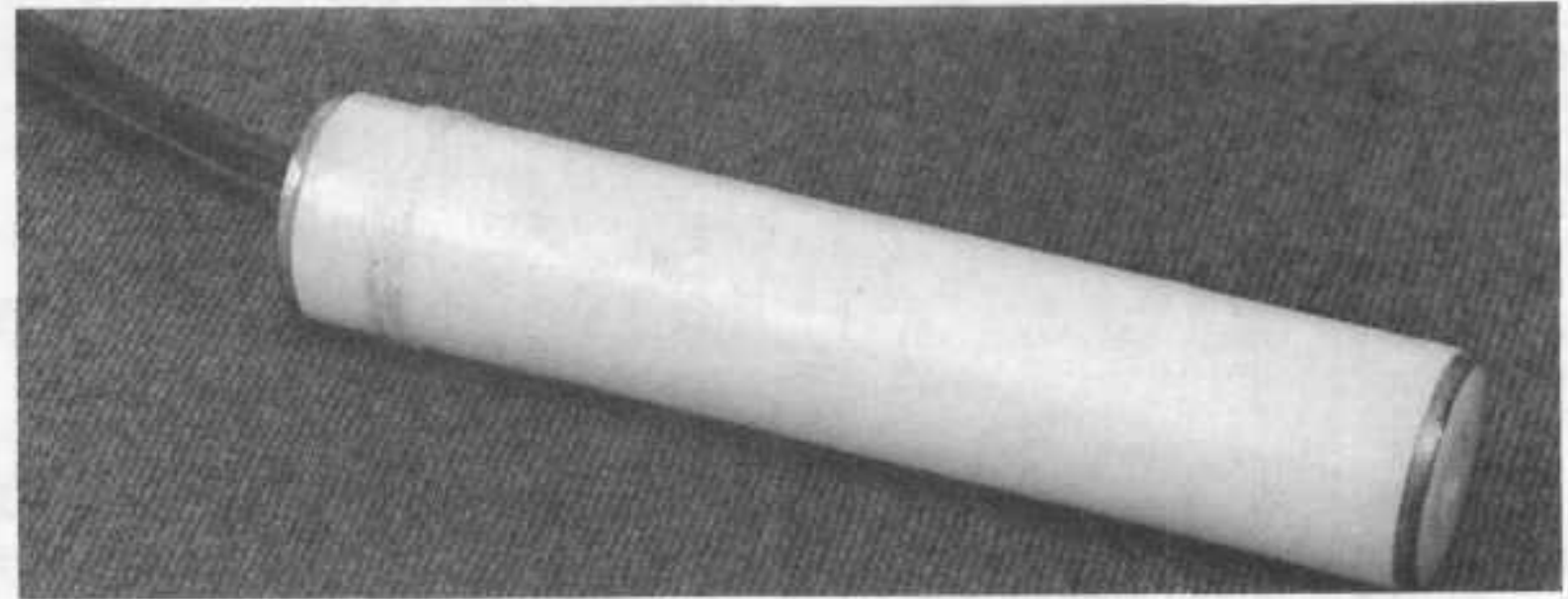

FIGURE 5. Close-Up of the Eddy-Current Probe Shown in Figure 4

because of their resultant penetration depths. The 4-MHz test is essentially a surface test except for very low conductivity graphites, while the other frequencies penetrate to correspondingly deeper levels in the graphite.

Our results have shown that a high degree of sophistication may be required to develop an algorithm which can estimate oxidation profiles. Analog computer methods which have been widely used for other multifrequency data combinations do not appear applicable to this problem. As a result, we have started development of an algorithm using large scale computing facilities. Programs Called EDDY and ZFIT have been implemented on the Brookhaven CDC-7600 computer. EDDY calculates resistance and reactance of a coil located above a conducting plane when coil geometery, driving frequency, and layer conductivities, thicknesses, and permeabilities are specified. Program EDDY is based on theory and codes developed by C. V. Dodd et al. (1973) at Oak Ridge National Laboratory. The program has been embedded in a parameter fitting routine MINUIT, available on the Brookhaven computer. The resulting program ZFIT searches for values of a specified list of graphite parameters to fit a set of impedance measurements. This corresponds to a form of inversion of the EDDY program in which resistance and reactance at several frequencies are used to estimate material properties versus depth. The fitting program makes possible the inversion which would be impossible or very difficult by other approaches.

Further work will be conducted on the algorithm to verify that it is a viable approach for estimating near surface oxidation profiles, and to determine the simplest form of the algorithm which could be implemented on portable field equipment. 


\section{PREPARATION OF SAMPLES}

Union Carbide(a) grade $P G X$ is a molded graphite, with medium grain size, available in large diameter logs. We acquired about one-eighth of a 1.14-m (45-in.)-diameter by $1.83-m$ (8-ft)-long log from General Atomic. (b)

As shown in Appendix A, we machined samples having three different geometries for use with the four techniques. These sample geometries are:

- Large cylinders, $76 \mathrm{~mm}$ ( 3 in.) in diameter, used to obtain data for direct comparison with our previous data (on strength, density, longitudinal velocity, and compressive strength, both before and after oxidation) for 4 other grades of graphite. Cylinders which were used to obtain the unoxidized properties were $152 \mathrm{~mm}$ (6 in.) long. Samples to be oxidized were $203 \mathrm{~mm}$ ( 8 in.) long, but were reduced to $152 \mathrm{~mm}$ long after oxidation and prior to measurement of the ir properties.

- Large blocks, $115 \times 165 \times 190 \mathrm{~mm}(4.5 \times 6.5 \times 7.5 \mathrm{in}$.), used for testing the ultrasonic surface wave, ultrasonic back scattering, and eddy-current techniques. The blocks were given a plasma sprayed coating of $\mathrm{ZrO}_{2}$ prior to oxidation; this coating retarded, but did not eliminate oxidation of the underlining graphite.

- Thin plates, $1.25 \mathrm{~mm}(0.050$ in.) thick and $76 \mathrm{~mm}$ ( 3 in.) square, were oxidized to various densities and used to simulate oxidation gradients for development of the eddy-current techniques.

\section{RESULTS}

The principle results obtained during this investigation are discussed below under the primary heading which designates the identifies the sample geometry. Additional information on the oxidation rate of $P G X$ is presented in Appendix B.

\section{LARGE CYLI NDERS}

In our previous investigations, we concentrated on the development of techniques that would be suitable for monitoring the strength changes of the core support posts. The graphite grades that we examined have finer grain size and higher strength than PGX. Thus, it was important to determine if the techniques that we had developed were applicable to $P G X$, and to provide a basis for comparison. The majority of the previous work had been performed on 76-mm (3-in.)-diameter by $152-\mathrm{mm}$ (6-in.)-long cylinders, before or after oxidation

(a) Union Carb ide Corporation, New York, NY 10017.

(b) General Atomic Company, San Diego, CA 92138. 
at $875^{\circ} \mathrm{C}$ in a mixture of $80 \% \mathrm{CO}_{2}, 20 \% \mathrm{CO}$; therefore, we chose to use the above geometry and oxidation conditions for one series of tests on PGX.

In our previous investigations, we established that there is a very high correlation between the compressive strength and certain properties. The general equation for this correlation can be written as:

$$
S=S_{0}\left(P / P_{0}\right)^{\alpha}
$$

where $S=$ the measured compressive strength of a sample.

$S_{0}=$ the average strength of unoxidized samples.

$\mathrm{P}=$ the measured value of the property(a) for the sample.

$P_{0}=$ the average value of the property as measured on unoxidized samples, and

$\alpha=$ a constant which varies with the grade of graphite and the specific property.

Table 2 lists the properties measured on unoxidized samples of PGX graphite and Table 3 shows the properties measured on other samples of PGX prior to their oxidation at $875^{\circ} \mathrm{C}$ in a mixture of $80 \% \mathrm{CO}_{2}$ and $20 \% \mathrm{CO}$. Table 4 ists the same properties, plus their compressive strength, measured after various amounts of oxidation. Table 5 shows the results of Rank Correlation Tests for al1 21 , oxidized and unoxidized samples. The differences in the absolute values of the correlation parameter, $R$, can be disregarded, because in all cases the probability of a correlation far exceeds $99 \%$.

It is interesting to note that neither unoxidized sample BA-7 or oxidized sample BA-1, which had unusually low densities (and, thus low values for their other properties), do not present anomalies in either the Rank Correlation Tests or in the Least Squares fit of the data to Equation 2. Table 6 shows the calculated unoxidized compressive strength, and the correlation coefficients obtained by least squares analys is of the data, as per Equation 2.

We had assumed (and to the best of our knowledge all previous investigators have assumed) that the oxidation rate would decrease as a continuous analytic function of distance from the surface.(b) However, visual

(a) The best correlations have been obtained for average sample density, and for the diametral ultrasonic velocities; however, very good correlations have been established for the axial ultrasonic velocities, and for the elastic and shear moduli, measured both in the diametral and axial directions.

(b) This assumption seems logical based on the fact that the concentration of the oxidant will decrease and the concentration of the oxidation products will increase with increasing penetration depth. 
TABLE 2. Property Measurements on Unoxidized PGX Cylinders

\begin{tabular}{|c|c|c|c|c|c|c|}
\hline \multirow[b]{2}{*}{ Sample No. } & \multirow[b]{2}{*}{$\begin{array}{l}\text { Strength } \\
(\mathrm{MPa})\end{array}$} & \multirow[b]{2}{*}{$\begin{array}{l}\text { Dens ity } \\
\left(\mathrm{Mg} / \mathrm{m}^{3}\right)\end{array}$} & \multicolumn{2}{|c|}{$\begin{array}{c}\text { Diametral } \\
\text { Measurements }\end{array}$} & \multicolumn{2}{|c|}{$\begin{array}{c}\text { Axial } \\
\text { Measurements }\end{array}$} \\
\hline & & & $\begin{array}{c}v_{f} \\
(\mathrm{~km} / \mathrm{s})\end{array}$ & 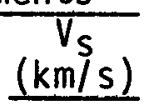 & $\begin{array}{c}V_{\mathrm{l}} \\
(\mathrm{km} / \mathrm{s})\end{array}$ & $\begin{array}{c}V_{\mathrm{s}} \\
(\mathrm{km} / \mathrm{s}) \\
\end{array}$ \\
\hline$A C-3$ & 39.20 & 1.749 & 2.096 & 1.392 & 1.909 & 1.345 \\
\hline$A C-4$ & 38.94 & 1.748 & 2.092 & 1.387 & 1.901 & 1.337 \\
\hline$A B-11$ & 38.87 & 1.751 & 2.103 & 1.395 & 1.912 & 1.345 \\
\hline$B A-6$ & 38.65 & 1.754 & 2.126 & 1.406 & 1.910 & 1.352 \\
\hline$A C-6$ & 38.55 & 1.749 & 2.108 & 1.397 & 1.915 & 1.345 \\
\hline BA-17 & 38.35 & 1.752 & 2.110 & 1.402 & 1.893 & 1.342 \\
\hline BA-4 & 37.99 & 1.746 & 2.101 & 1.383 & 1.896 & 1.345 \\
\hline$A C-5$ & 37.75 & 1.747 & 2.088 & 1.384 & 1.904 & 1.336 \\
\hline$A C-2$ & 36.78 & 1.747 & 2.106 & 1.393 & 1.909 & 1.340 \\
\hline BA-15 & 36.09 & 1.746 & 2.104 & 1.398 & 1.886 & 1.342 \\
\hline$B A-2$ & 35.88 & 1.733 & 2.081 & 1.384 & 1.890 & 1.335 \\
\hline$B A-7$ & 29.10 & 1.690 & 1.972 & 1.311 & 1.763 & 1.265 \\
\hline Average: & 37.18 & 1.743 & 2.091 & 1.386 & 1.891 & 1.336 \\
\hline $\pm 1 \sigma:$ & 2.78 & 0.013 & 0.039 & 0.025 & 0.041 & 0.023 \\
\hline
\end{tabular}

NOTE: Sample $A B-22$ was cut with its long axis transverse to the long axis of the other samples; thus, neither the diametral no axial velocities are directly comparable with the values measured on the other samples.

examination of sectioned samples of oxidized PGX indicates that there is an area of increased porosity below the surface. Physical measurements of density confirm the visual indications that there was an increase in oxidation rate with penetration depth. Figure 6 shows a optical view of a $25-\mathrm{mm}$ thick disk, cut from the end of an oxidized 76-mm diameter sample; and Figure 7 shows the density profile obtained by physical measurements on another PGX sample.

A review of the literature indicates that th is inverse oxidation phenomenon has been observed by Walker et al. (1968)(a) at Pennsylvania State

(a) See especially p. 366 of the reference. 
TABLE 3. Pre-0xidation Measurements on PGX Cylinders

\begin{tabular}{|c|c|c|c|c|c|}
\hline \multirow[b]{2}{*}{ Sample No. } & \multirow[b]{2}{*}{$\begin{array}{l}\text { Density } \\
\left(\mathrm{Mg} / \mathrm{m}^{3}\right) \\
\end{array}$} & \multicolumn{2}{|c|}{$\begin{array}{r}\text { Diametral } \\
\text { Velocities } \\
\end{array}$} & \multicolumn{2}{|c|}{$\begin{array}{c}\text { Axial } \\
\text { Velocities } \\
\end{array}$} \\
\hline & & $\begin{array}{c}V_{\ell} \\
(\mathrm{km} / \mathrm{s}) \\
\end{array}$ & $\begin{array}{c}V_{\mathrm{s}} \\
(\mathrm{km} / \mathrm{s}) \\
\end{array}$ & $\begin{array}{c}V_{l} \\
(\mathrm{~km} / \mathrm{s}) \\
\end{array}$ & $\begin{array}{r}V_{\mathrm{s}} \\
(\mathrm{km} / \mathrm{s}) \\
\end{array}$ \\
\hline$B A-3$ & 1.744 & 2.089 & 1.390 & 1.905 & 1.346 \\
\hline BA-5 & 1.745 & 2.097 & 1.392 & 1.902 & 1.348 \\
\hline BA-16 & 1.746 & 2.104 & 1.396 & 1.901 & 1.348 \\
\hline$B A-10$ & 1.747 & 2.095 & 1.392 & 1.902 & 1.348 \\
\hline$B A-11$ & 1.747 & 2.105 & 1.397 & 1.900 & 1.347 \\
\hline$B A-1$ & 1.684 & 1.950 & 1.303 & 1.768 & 1.255 \\
\hline BA-8 & 1.739 & 2.081 & 1.387 & 1.901 & 1.345 \\
\hline$B A-12$ & 1.754 & 2.117 & 1.409 & 1.920 & 1.357 \\
\hline $\mathrm{BA}-14$ & 1.741 & 2.092 & 1.391 & 1.890 & 1.342 \\
\hline & 1.739 & 2.081 & 1.384 & 1.888 & 1.337 \\
\hline $\pm 10:$ & 0.021 & 0.050 & 0.031 & 0.046 & 0.031 \\
\hline
\end{tabular}

TABLE 4. Property Measurements on 0xidized PGX Cylinders

\begin{tabular}{|c|c|c|c|c|c|c|}
\hline \multirow[b]{2}{*}{ Sample No. } & \multirow[b]{2}{*}{$\begin{array}{l}\text { Strength } \\
(\mathrm{MPa}) \\
\end{array}$} & \multirow[b]{2}{*}{$\begin{array}{l}\text { Density } \\
\left(\mathrm{Mg} / \mathrm{m}^{3}\right) \\
\end{array}$} & \multicolumn{2}{|c|}{$\begin{array}{c}\text { Diametral } \\
\text { Measurements }\end{array}$} & \multicolumn{2}{|c|}{$\begin{array}{c}\text { Axial } \\
\text { Measurements }\end{array}$} \\
\hline & & & $\begin{array}{c}V_{\ell} \\
(\mathrm{km} / \mathrm{s}) \\
\end{array}$ & $\begin{array}{c}\begin{array}{c}V_{\mathrm{s}} \\
(\mathrm{km} / \mathrm{s})\end{array} \\
\end{array}$ & $\begin{array}{c}V_{l} \\
(\mathrm{~km} / \mathrm{s}) \\
\end{array}$ & $\begin{array}{c}\begin{array}{c}V_{\mathrm{s}} \\
(\mathrm{km} / \mathrm{s})\end{array} \\
\end{array}$ \\
\hline$B A-3$ & 31.67 & 1.709 & 1.933 & 1.297 & 1.762 & 1.250 \\
\hline$B A-5$ & 29.33 & 1.676 & 1.869 & 1.250 & 1.690 & 1.202 \\
\hline$B A-16$ & 23.02 & 1.642 & 1.851 & 1.235 & 1.665 & 1.251 \\
\hline$B A-10$ & 22.96 & 1.568 & 1.360 & 1.025 & 1.631 & 1.089 \\
\hline $\mathrm{BA}-11$ & 21.29 & 1.581 & 1.390 & 1.041 & 1.668 & 1.110 \\
\hline $\mathrm{BA}-1$ & 18.51 & 1.561 & 1.579 & 1.079 & 1.329 & 1.054 \\
\hline BA-8 & 18.44 & 1.544 & 1.243 & 1.007 & 1.628 & 1.094 \\
\hline BA-12 & 17.48 & 1.512 & 1.387 & 1.031 & 1.594 & 1.069 \\
\hline$B A-14$ & 16.11 & 1.511 & 1.305 & 0.958 & 1.547 & 1.032 \\
\hline Average: & 22.09 & 1.589 & 1.546 & 1.103 & 1.613 & 1.128 \\
\hline
\end{tabular}


TABLE 5. Rank Correlation Tests on PGX Cylinders

\begin{tabular}{|c|c|c|c|c|c|c|c|c|c|c|c|}
\hline \multirow{2}{*}{$\begin{array}{c}\text { Sample le } \\
\text { No. }\end{array}$} & \multirow[b]{2}{*}{ Strength } & \multirow[b]{2}{*}{ Density } & \multirow[b]{2}{*}{$\Delta^{2}$} & \multicolumn{4}{|c|}{$\begin{array}{l}\text { Diametral } \\
\text { Measurements }\end{array}$} & \multicolumn{4}{|c|}{$\begin{array}{c}\text { Axial } \\
\text { Measurements }\end{array}$} \\
\hline & & & & $\underline{v}_{\ell}$ & $\Delta^{2}$ & $\underline{v}_{s-}$ & $\Delta^{2}$ & $\underline{v}_{\ell-}$ & $\Delta^{2}$ & $v_{-S}$ & $\Delta$ \\
\hline$A C-3$ & 1 & 4.5 & 12.25 & 8 & 49 & 7 & 36 & 4.5 & 12.25 & 3.5 & 6.25 \\
\hline$A C-4$ & 2 & 6 & 16 & 9 & 49 & 8 & 36 & 7 & 25 & 9 & 49 \\
\hline$A B-11$ & 3 & 3 & 0 & 6 & 9 & 5 & 4 & 2 & 1 & 3.5 & 0.25 \\
\hline BA-6 & 4 & 1 & 9 & 1 & 9 & 1 & 9 & 3 & 1 & 1 & 9 \\
\hline$A C-6$ & 5 & 4.5 & 0.25 & 3 & 4 & 4 & 1 & 1 & 16 & 3.5 & 2.25 \\
\hline$B A-17$ & 6 & 2 & 16 & 2 & 16 & 2 & 4 & 9 & 9 & 6.5 & 0.25 \\
\hline BA-4 & 7 & 9.5 & 6.25 & 7 & 0 & 11 & 16 & 8 & 1 & 3.5 & 12.25 \\
\hline$A C-5$ & 8 & 7.5 & 0.25 & 10 & 4 & 9.5 & 2.25 & 6 & 1 & 10 & 4 \\
\hline$A C-2$ & 9 & 7.5 & 6.25 & 4 & 25 & 6 & 9 & 4.5 & 20.25 & 8 & 1 \\
\hline BA-15 & 10 & 9.5 & 0.25 & 5 & 25 & 3 & 49 & 11 & 1 & 6.5 & 12.25 \\
\hline $\mathrm{BA}-2$ & 11 & 11 & 0 & 11 & 0 & 9.5 & 2.25 & 10 & 1 & 11 & 0 \\
\hline$B A-3^{(a)}$ & 12 & 12 & 0 & 13 & 1 & 13 & 1 & 13 & 1 & 14 & 4 \\
\hline$B A-5^{(a)}$ & 13 & 14 & 1 & 14 & 1 & 14 & 1 & 14 & 1 & 15 & 4 \\
\hline$B A-7$ & 14 & 13 & 1 & 12 & 4 & 12 & 4 & 12 & 4 & 12 & 4 \\
\hline$B A-16(a)$ & 15 & 15 & 0 & 15 & 0 & 15 & 0 & 16 & 1 & 13 & 4 \\
\hline$B A-10^{(a)}$ & 16 & 17 & 1 & 19 & 9 & 19 & 9 & 17 & 1 & 18 & 4 \\
\hline$B A-11^{(a)}$ & 17 & 16 & 1 & 17 & 0 & 17 & 0 & 15 & 4 & 16 & 1 \\
\hline$B A-1^{(a)}$ & 18 & 18 & 0 & 16 & 4 & 16 & 4 & 21 & 9 & 20 & 4 \\
\hline$B A-8^{(a)}$ & 19 & 19 & 0 & 21 & 4 & 20 & 1 & 18 & 1 & 17 & 4 \\
\hline$B A-12^{(a)}$ & 20 & 20 & 0 & 18 & 4 & 18 & 4 & 19 & 1 & 19 & 1 \\
\hline$B A-14(a)$ & 21 & 21 & 0 & 20 & 1 & 21 & 0 & 20 & 1 & 21 & 0 \\
\hline$\Sigma \Delta^{2}:$ & & & 70.5 & & 220 & & 192.5 & & 112.5 & & 126.5 \\
\hline$R=$ & $\frac{6 \Sigma \Delta^{2}}{n^{2}-11}$ & & 0.954 & & 0.857 & & 0.875 & & 0.927 & & 0.918 \\
\hline
\end{tabular}

(a) Measurements after oxidation. 
TABLE 6. Calculated Compressive Strengths(a)

\begin{tabular}{|c|c|c|}
\hline Property & $\mathrm{MPa} \quad 0$ & $\alpha$ \\
\hline Density & $36.9 \pm 1.3$ & 5.66 \\
\hline \multicolumn{3}{|l|}{ Diametral Measurements } \\
\hline Longitudinal velocity & $36.2 \pm 2.8$ & 1.54 \\
\hline Shear-wave velocity & $36.7 \pm 2.1$ & 2.21 \\
\hline Elastic modulus & $35.9 \pm 3.0$ & 0.62 \\
\hline Shear modulus & $36.8 \pm 2.0$ & 0.93 \\
\hline \multicolumn{3}{|l|}{ Axial Measurements } \\
\hline Longitudinal velocity & $36.1 \pm 2.7$ & 2.94 \\
\hline Shear-wave velocity & $36.9 \pm 2.2$ & 3.08 \\
\hline Elastic modulus & $36.0 \pm 2.6$ & 1.04 \\
\hline Shear modulus & $36.0 \pm 1.9$ & 1.22 \\
\hline
\end{tabular}

(a) Measured compressive strength is $37.2 \pm 2.8 \mathrm{MPa}$ (see Table 2).

University and by others at Oak Ridge National Laboratory (ORNL).(a) Moreover this phenomenon is not isolated to PGX graphite, nor is it isolated to samples oxidized in a mixture of $\mathrm{CO}_{2}$ and $\mathrm{CO}$. Because of the potential significance of this phenomenon to the oxidation behavior of graphite in an operating HTGR, we have performed additional work to investigate this phenomenon.

Disks ( $76 \mathrm{~mm}$ in dia, $25 \mathrm{~mm}$ thick), which had been cut from the ends of oxidized cylinders (Morgan and Becker 1979), were ashed in air at $700^{\circ} \mathrm{C}$. Table 7 shows the elemental composition of the ash; the analys is was made by $X$-ray Photoelectron Spectroscopy; Morgan and Thomas (1981) have published details of the analysis and visual observations of the ash. It was not possible to determine which of the impurity elements are responsible for the inverse oxidation phenomenon; however, the catalytic activity of many impurities is known (Mckee 1980) to be strongly dependent on the chemical state of the impurity element.

It seems most likely that the increased oxidation rate in the interior of these samples resulted from a change in oxidation state of one or more of the impurity elements as a result of the change in the $\mathrm{CO} / \mathrm{CO}_{2}$ ratio with distance from the surface (Morgan and Thomas 1982). The possiblity that this phenomenon might occur in the reactor core-support components $c$ annot be ruled out at the

(a) Conversations with W. P. Eatherly (ORNL). 
PGX, SA. NO. VII-BA-12

$$
\begin{aligned}
& P_{0}=1.754 \\
& \rho=1.512 \\
& \Delta p=13.8 \%
\end{aligned}
$$

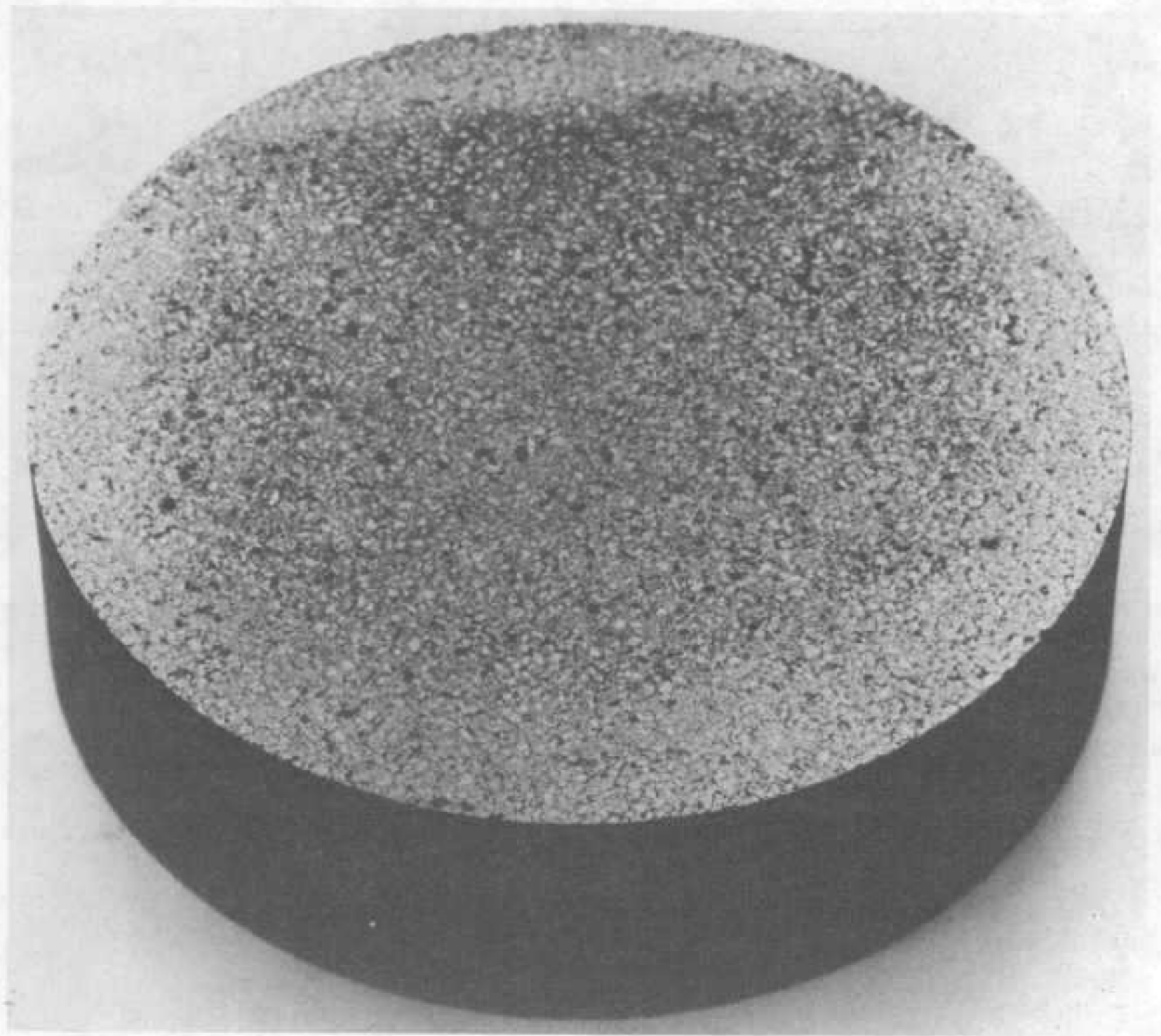

FIGURE 6. Sectioned Sample of 0xidized PGX Graphite

present time. Thus, it will be necessary to obtain oxidation depth profiles rather than merely extrapolating the near-surface oxidation profiles. 


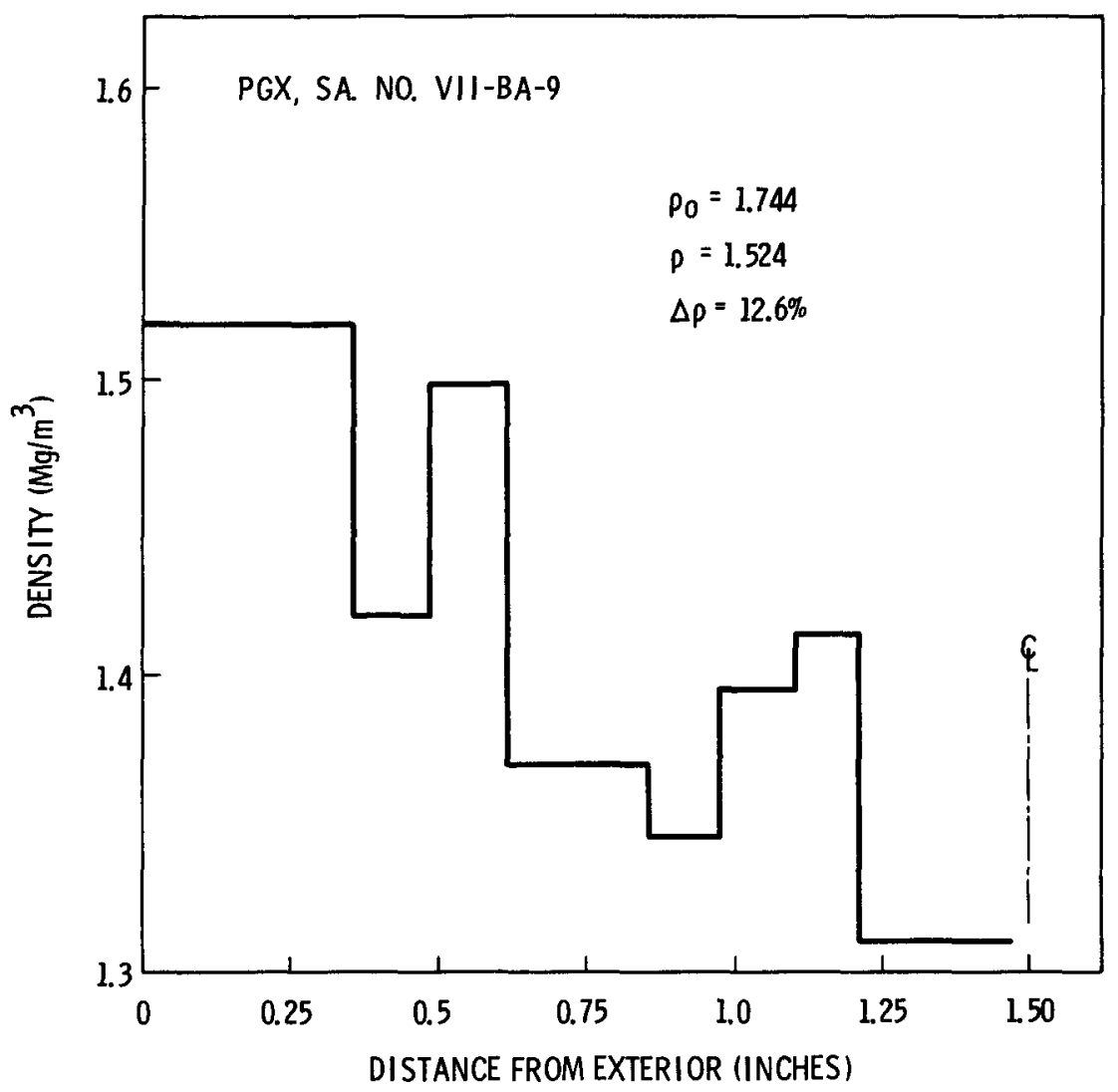

FIGURE 7. Density Versus 0xidation Depth for a 3.0-in. Diameter Sample 
TABLE 7. Elemental Composition of Graphite Ash

Samp le No:

\begin{tabular}{c} 
Graphite Grade: (a) \\
Total Ash, ppm: \\
Element \\
\hline
\end{tabular}

$$
\text { I I-D-3 II }-F-3 \text { II I-A-12 }
$$

II I-A-10

$\mathrm{V}-\mathrm{A}-7$

$V I-A-4 \quad V I I-B A-3$

2020

2020-P $\$ 1090$

S1090-P

ATJ

P3W

$P G X$

Ca

$\underline{970} \quad 32$

1030

17

$\underline{800} \quad 2410 \quad 3820$ Concentration, atomic percent

\begin{tabular}{ccccccc}
\hline 18.5 & 5.5 & 9.4 & 3.9 & 13.3 & 33.5 & 1.1 \\
18.8 & 1.9 & 15.4 & 1.9 & 23.6 & 3.8 & 6.6 \\
1.0 & -- & 0.4 & -- & 1.5 & 0.2 & 0.5 \\
-- & 0.6 & -- & 1.5 & -- & 2.7 & 3.0 \\
0.1 & -- & 0.1 & -- & 0.1 & 0.1 & 0.1 \\
2.8 & -- & 1.0 & -- & 2.4 & 0.8 & 0.6 \\
1.3 & 3.0 & 0.8 & -- & 0.8 & 0.9 & 2.4 \\
1.3 & -- & -- & -- & -- & -- & 2.3 \\
0.8 & -- & 14.6 & -- & 0.8 & -- & 5.7 \\
0.3 & -- & -- & -- & -- & -- & 0.9 \\
-- & 0.3 & -- & 0.3 & -- & -- & 1.2 \\
- & 1.8 & -- & 3.3 & - & -- & -- \\
- & 11.6 & -- & 8.1 & -- & -- & -- \\
- & 1.0 & -- & 2.0 & - & -- & -- \\
- & 0.1 & -- & 0.1 & -- & -- & --
\end{tabular}

0

$51.5 \quad 45.1$

55.8

42.8

51.5

53.4

49.7

c

$3.5 \quad 29.2$

2.4

36.1

6.0

4.5

5.4

(a) Samples which had been purified by POCO Graphite, Inc., were designated 2020-P and S1090-P.

\section{LARGE BLOCKS}

The large (115- x 165- x 190-mm) blocks were intended for use in developing the eddy-current techniques for measuring the near-surface oxidation profile; therefore, we wanted to obtain a large surface area with a fairly uniform oxidation gradient into the block. In order to increase the amount of surface area which was uniformly oxidized (i.e., to minimize the edge-effects), we plasma sprayed a thin coating of $\mathrm{ZrO}_{2}$ on bottom surface and four sides of the blocks, leaving a 165- x 190-mm uncoated surface to be exposed to the oxidizing gasses. This coating adhered well to the graphite, but was somewhat porous, and did not completely eliminate oxidation of the underlying graphite. 
In order to develop different oxidation profiles, the blocks were oxidized at different temperatures in $\mathrm{CO}_{2}-\mathrm{CO}$, as shown in Table 8. After oxidation, a 30-mm-thick slab was cut from one end of each block and the oxidation patterns, noted in Table 8, were observed. A second slab $(115 \times 165 \times 15 \mathrm{~mm})$ was cut from the block and a sample $(15 \times 15 \times 115 \mathrm{~mm})$ was machined from the center portion of the slab. The density profile in this small sample was obtained by incrementally reducing its length and measuring the weight loss for each increment. The resultant density profiles are shown in Figures 8 through 10 . The positions from which these samples were taken were chosen such that they would be most representative of the uniformly oxidized material in the block.

TABLE 8. Data on Oxidation of PGX Blocks

\begin{tabular}{|c|c|c|c|}
\hline $\begin{array}{c}\text { Block } \\
\text { No. }\end{array}$ & $\begin{array}{l}\text { Oxidation } \\
\text { Temperature } \\
\left.\text { ( }{ }^{\circ} \mathrm{C}\right)\end{array}$ & $\begin{array}{c}\text { Weight } \\
\text { Loss }(a) \\
(\%)\end{array}$ & $\begin{array}{l}\text { Oxidation } \\
\text { Atmosphere } \\
\text { (\% by Volume) (b }\end{array}$ \\
\hline AA-4 & 875 & 10.5 & $80 \% \mathrm{CO}_{2} / 20 \% \mathrm{CO}$ \\
\hline$A A-1$ & 925 & 10.6 & $80 \% \mathrm{CO}_{2} / 20 \% \mathrm{CO}$ \\
\hline$A A-3$ & 975 & 7.5 & $94 \% \mathrm{CO}_{2} / 6 \% \mathrm{CO}$ \\
\hline AA-2 & 1025 & 5.0 & $94 \% \mathrm{CO}_{2} / 6 \% \mathrm{CO}$ \\
\hline$A B-3$ & 1025 & 12 & $94 \% \mathrm{CO}_{2} / 6 \% \mathrm{CO}$ \\
\hline
\end{tabular}

\begin{tabular}{l} 
Condition of the \\
Cross-sectioned Surface \\
\hline Broad band of oxidation pit- \\
ting, from $\sim 10$ to $40 \mathrm{~mm}$ be low \\
surface. \\
Narrow band of pitting, from \\
$\sim 6$ to $12 \mathrm{~mm}$ be low surface. \\
Very narrow band of pitting, \\
from $\sim 3$ to $5 \mathrm{~mm}$ below surface. \\
Anomalous oxidation pattern; \\
not sectioned (see text). \\
Reduced to granular powder to \\
a depth of $\sim 3$ to $5 \mathrm{~mm}$ below \\
surface; not sectioned.
\end{tabular}

(a) See Appendix B for oxidation rate.

(b) Composition of gas entering the furnace. At $875^{\circ} \mathrm{C}$, about $1 \%$ of the $\mathrm{CO}_{2}$ reacted wih the graphite sample; at $925^{\circ} \mathrm{C}$ and $975^{\circ} \mathrm{C}$ about $4 \%$ reacted; at $1025^{\circ} \mathrm{C}$ about $11 \%$ reacted.

The surface of Block $A B-3$ appeared solid, except in a few. patches where 27 grams of particles had sluffed off (the block was oxidized standing on end in the furnace); however, the slightest pressure would dislodge large patches of granular particles. Block $A A-2$ had what appeared to be a flow line running diagonally the length of the block; that is, a "pitch-rich" line which had been produced during the mixing, or the molding operation, when one part of the mixture flowed relative to an adjacent part of the mixture. This line was quite visible optically, and eddy-current measurements indicated that there was an abrupt change in density at this line. After oxidation, eddy-current measurements showed an even larger demarcation in density at the line and a 


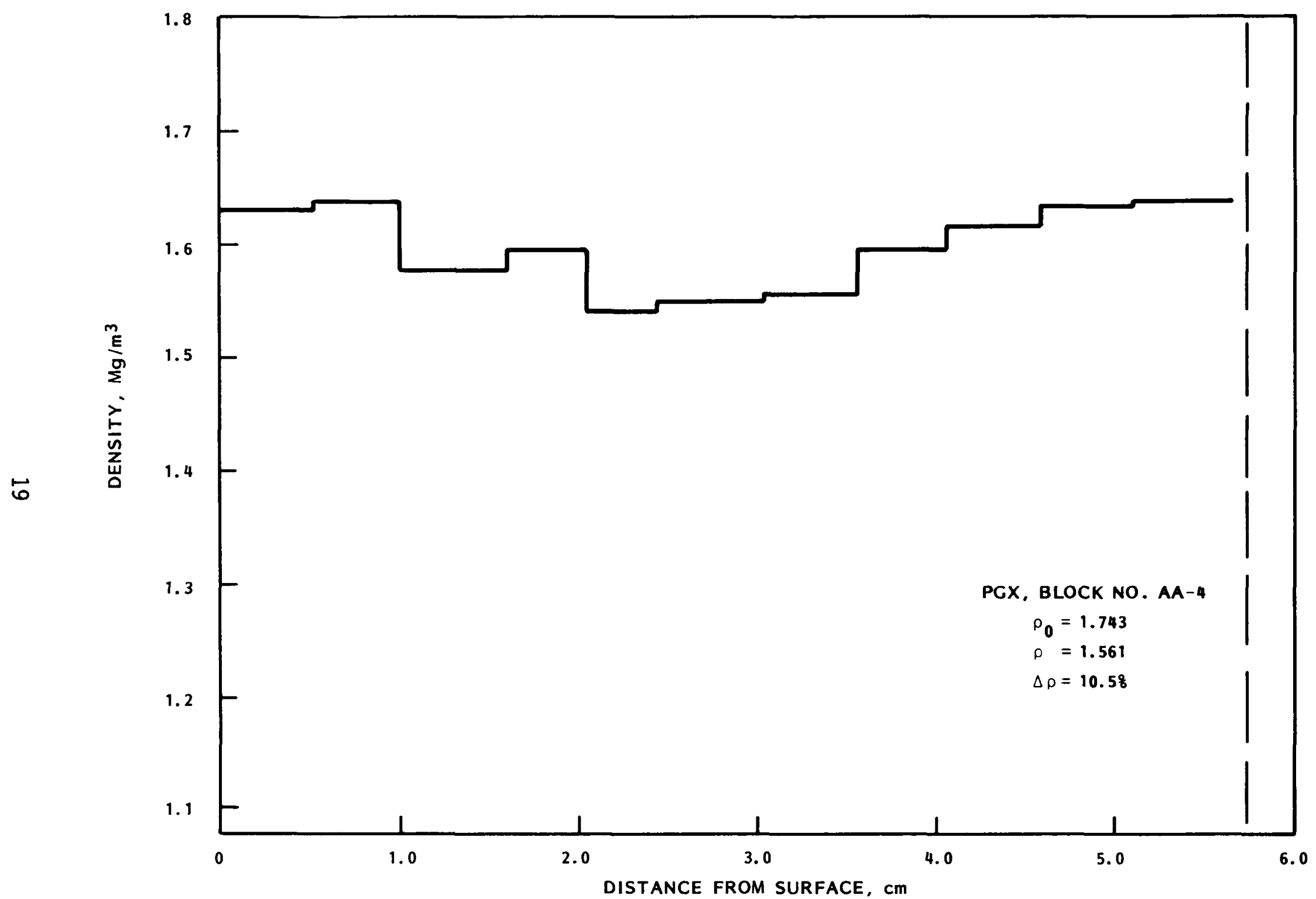

FIGURE 8. Density-Depth Profile for Block 0xidized at $875^{\circ} \mathrm{C}$ 


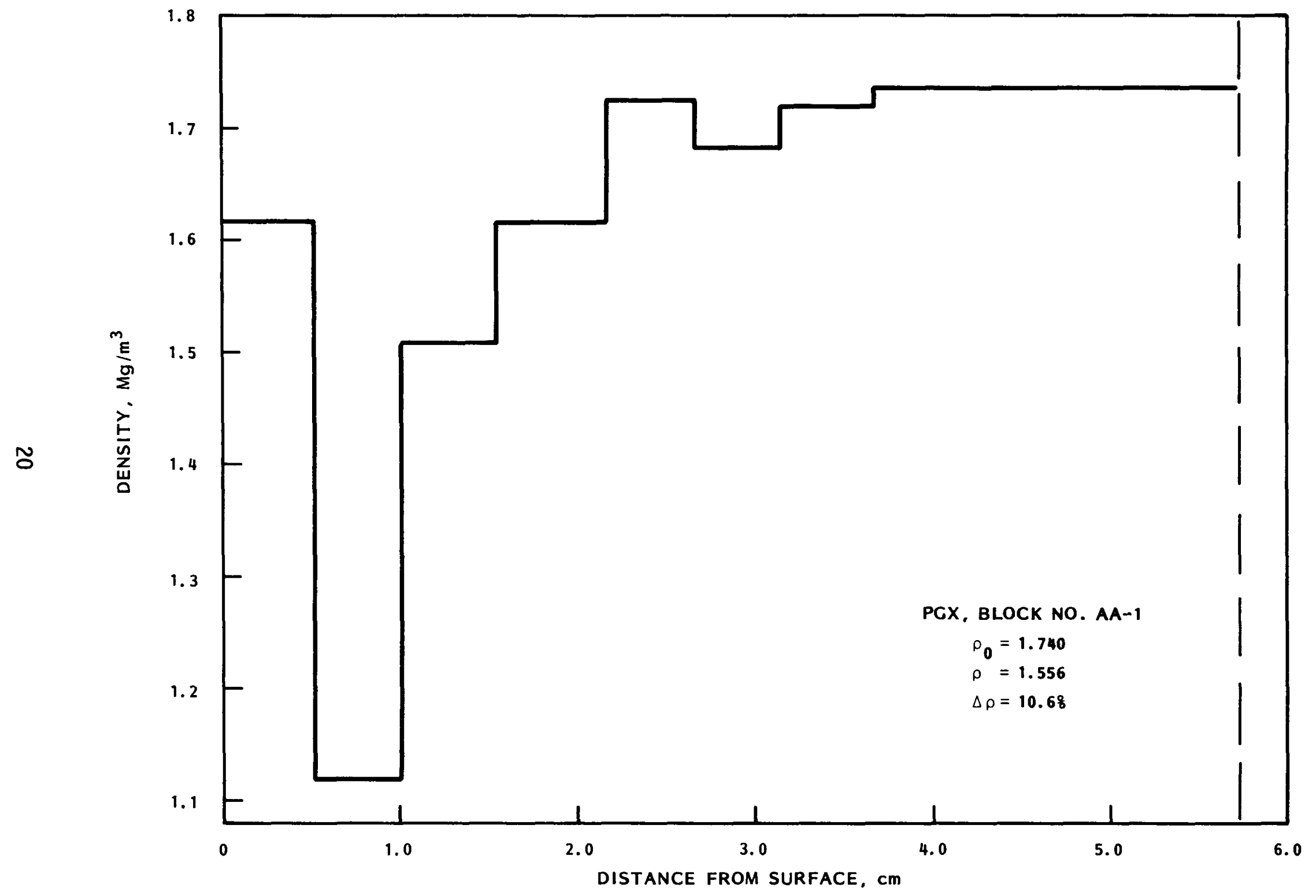

FIGURE 9. Density-Depth Profile for Block Oxidized at $925^{\circ} \mathrm{C}$ 


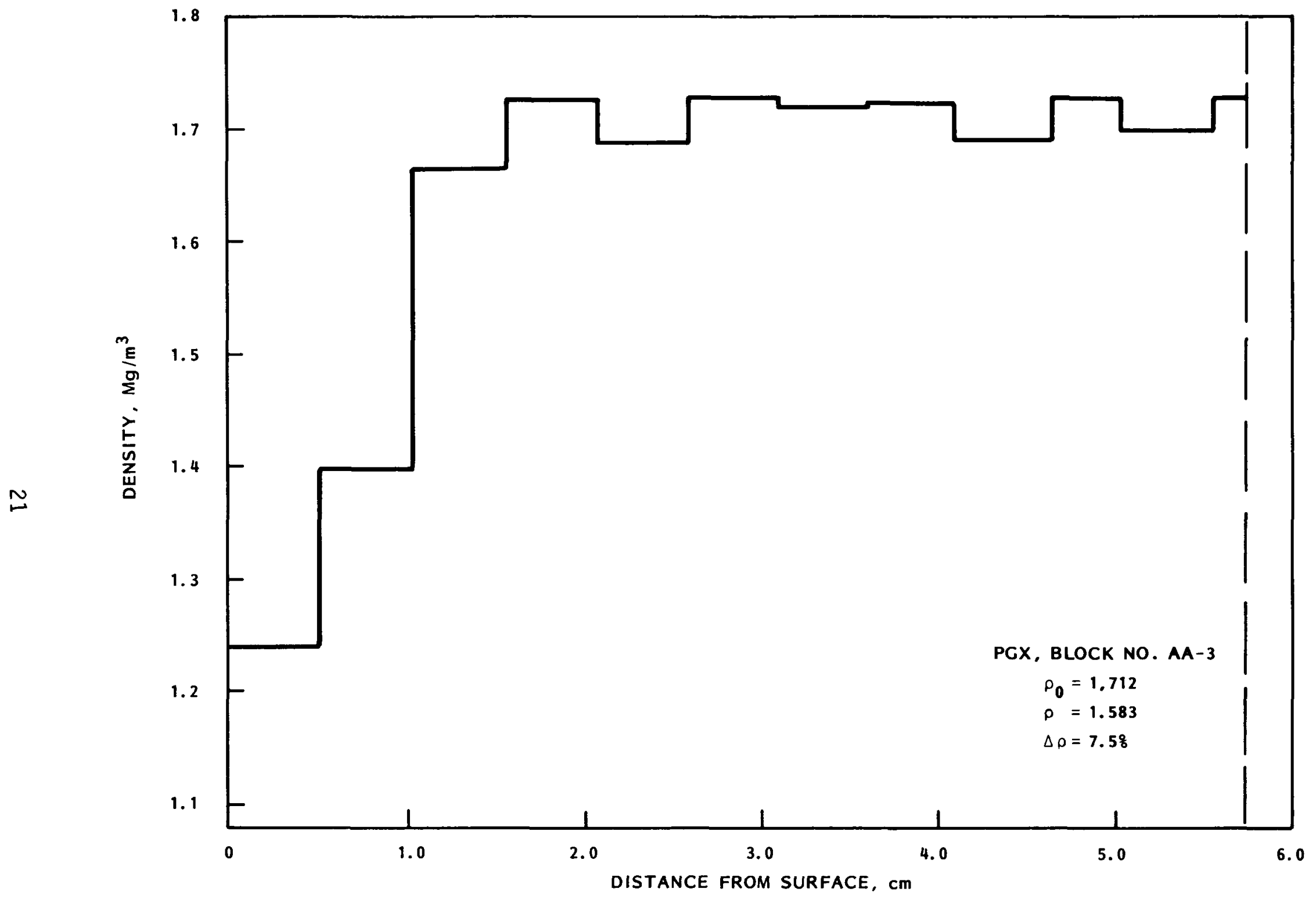

FIGURE 10. Density-Depth Profile for Block Oxidized at $1025^{\circ} \mathrm{C}$ 
superimposed gradient, which was apparently caused by a gradient in catalytic impurities within the denser part of the block. The corner farthest from the flow line was very friable.

The other blocks seemed to be of fairly uniform density (as indicated by the eddy-current measurements) prior to oxidation. After oxidation, Block AA-3 had a side-to-side gradient in density with a small patch (roughly 20 to $40 \mathrm{~mm}$ across) of medium density toward the edge having the lowest density. Eddycurrent measurements indicated that Block $A A-1$ and half of Block $A A-4$ had been quite uniformly oxidized; the other half of Block AA-4 had a decreasing density with distance from the center and, particularly, toward one corner.

The observed density profiles lend strong support to the existance of the inverse oxidation phenomenon, discussed in the previous section. The results also indicate that PGX (or, at least, this log of PGX) is a highly variable material and that large differences in oxidation rate can be expected within the FSVR core-support blocks.

\section{THIN PLATES}

The thin (1.25-mm-thick) plates were prepared to serve as density standards to aid in the development of the algorithm used to obtain density profiles from the eddy-current data. By stacking plates of different densities, one can obtain a stepwise simulation of any density profile, and one can directly determine the contribution of different layers to the overall response of the equipment. A total of 37 plates were cut from piece $A B-12$; 31 of these plates were oxidized in $80 \% \mathrm{CO}_{2} / 20 \% \mathrm{CO}$ at $875^{\circ} \mathrm{C}$ so as to obtain series from 0.2 to over $20 \%$ oxidation.

A wide variety of oxidation profiles were simulated by stacks of these plates and eddy-current data were obtained at three frequencies, as discussed on pages 6 and 8 . Actual calibration of the equipment will require preparation of thicker samples; however, use of the thin plates to simulate oxidation profiles has been a definite aid in developing the eddy-current technique and in perfecting the data processing algorithm ZFIT.

\section{ACKNOWLEDGMENTS}

The authors gratefully acknowledge the contributions of C. B. Perry, P. L. Tomeraasen, J. C. Harr is, F. D. Hobbs, and R. T. Landsiedel. We also appreciate the ass istance provided by G. B. Engle and L. A. Beavan of the General Atomic Company. 


\section{REFERENCES}

Baldwin, N. L., and J. R. Wolfer. 1978. "Fort St. Vrain Startup Test B-2, Analysis of Chemical Impurities in the Primary Coolant. Interim Report No. 4, Sequences 45 through 61 (70\% power)," GA-D14713.

Burnette, R. D., W. E. Bell, R. F. Turner, and W. J. Knapp. 1971. "Chemical Impurities in the Helium Coolant at the Peach Bottom HTGR," GULF-GA-A10809.

Carlyle, M., and D. V. Kinsey. 1969. "Results of the Injection of Impurities into the Dragon Reactor Primary Coolant," D. P. Report 544.

Chapman, B. G. 1970. "Dragon Operating Experience," Proc. Gas-Cooled Reactor Information Meeting, CONF-700401, pp. 3-33.

Dahlberg, R. C., R. R. Turner, and W. V. Goeddel. 1969. "Core Design Characteristics," Nucl. Eng. Intern. 14:1073

Dodd, C. V., C. C. Cheng, W. A. Simpson, D. A. Deeds, and J. H. Smith. 1973. The Analys is of Ref lection Type Coils for Eddy-Current Testing, ORNL-TM-4107.

Eto, M., and F. B. Growcock. 1981. "Effect of Oxidizing Environment on the Strength and 0xidation Kinetics of HTGR Graphites", NUREG/CR-2480.

Fortescue, P., D. Nicoll, C. Rickard and D. Rose. 1960. "HTGR--Underlying Principles and Design," Nucleonics 18:86

Goebbels K. 1980. "Structure Analysis by Scatter Ultrasonic Radiation." Research Techniques in Nondestructive Testing, Vol. IV (R. S. Sharpe, editor), Academic Press, New York, New York.

McKee, D. M. 1980. "The Catalyzed Gasification Reactions of Carbon." Chemistry and Physics of Carbon, Vol 16 (P. L. Walker, Jr. and P. A. Thrower, editors) Marcel Dekker, New York, New York, pp. 1-118.

Montgomery, F. C., and R. D. Burnette. 1976. "Fort St. Vrain Startup Test B-2, Analysis of Chemical Impurities in the Primary Coolant. Interim Report No. 1, Through Sequence 23 (27\% power)," GA-D14138.

Montgomery, F. C., and R. D. Burnette. 1977. "Fort St. Vrain Startup Test B-2, Analysis of Chemical Impurities in the Primary Coolant. Interim Report No. 2, Sequences 24 through 31 (28\% power)," GA-D14346.

Montgomery, F. C., and N. L. Baldwin. 1977. "Fort St. Vrain Startup Test B-2, Analys is of Chemical Impurities in the Primary Coolant. Interim Report No. 3, Sequences 32 through 44 (38\% power)," GA-D14713.

Morgan, W. C., and F. L. Becker. 1974. In-Service Monitoring of the Strength of HTGR Core Support Structure, BNWL-B-359. 
Morgan, W. C., and F. L. Becker. 1977. Feasibility of Monitoring the Strength of HTGR Core Support Graphite--Part I, BNWL-2239.

Morgan, W. C., and F. L. Becker. 1979. Feasibility of Monitoring the Strength of HTGR Core Support Graphite--Part II. NUREG/CR-0995.

Morgan, W. C., and M. T. Thomas. 1981. "Catalytic Activity of Impurities in Graphites", 15th Biennial Conference on Carbon, CONF-810604, pp. 409-410.

Morgan, W. C. and M. T. Thomas. 1982. "The Inverse Oxidation Phenomenon," Carbon 20:71.

Walker, P. L. Jr., M. Shelef, and R. A. Anderson. 1968. "Catalysis of Carbon Gasification," Chemistry and Physics of Carbon, Vol. 4 (P. L. Walker, Jr.

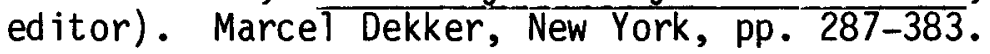

Walker R. E. and T. A. Johnston. 1969. "Fort St. Vrain Nuclear Power Station," Nuc1. Eng. Intern. 14:1069. 
APPENDIX A

SAMPLING SCHEMES AND PREPARATION OF SAMPLES 


\section{SAMPLING SCHEMES AND PREPARATION OF SAMPLES}

A one-eighth section of a PGX log (General Atomic Company Log No. 7637-57; Union Carbide Corp. Log No. 36K5) was obtained from General Atomic. Figure A.1 shows a perspective view of this section and shows the location of the slabs cut from this section. Figures A.2, and A.3 show the locations from which the samples were cut from the slabs. Other details of sample preparation are given in Table A.1.

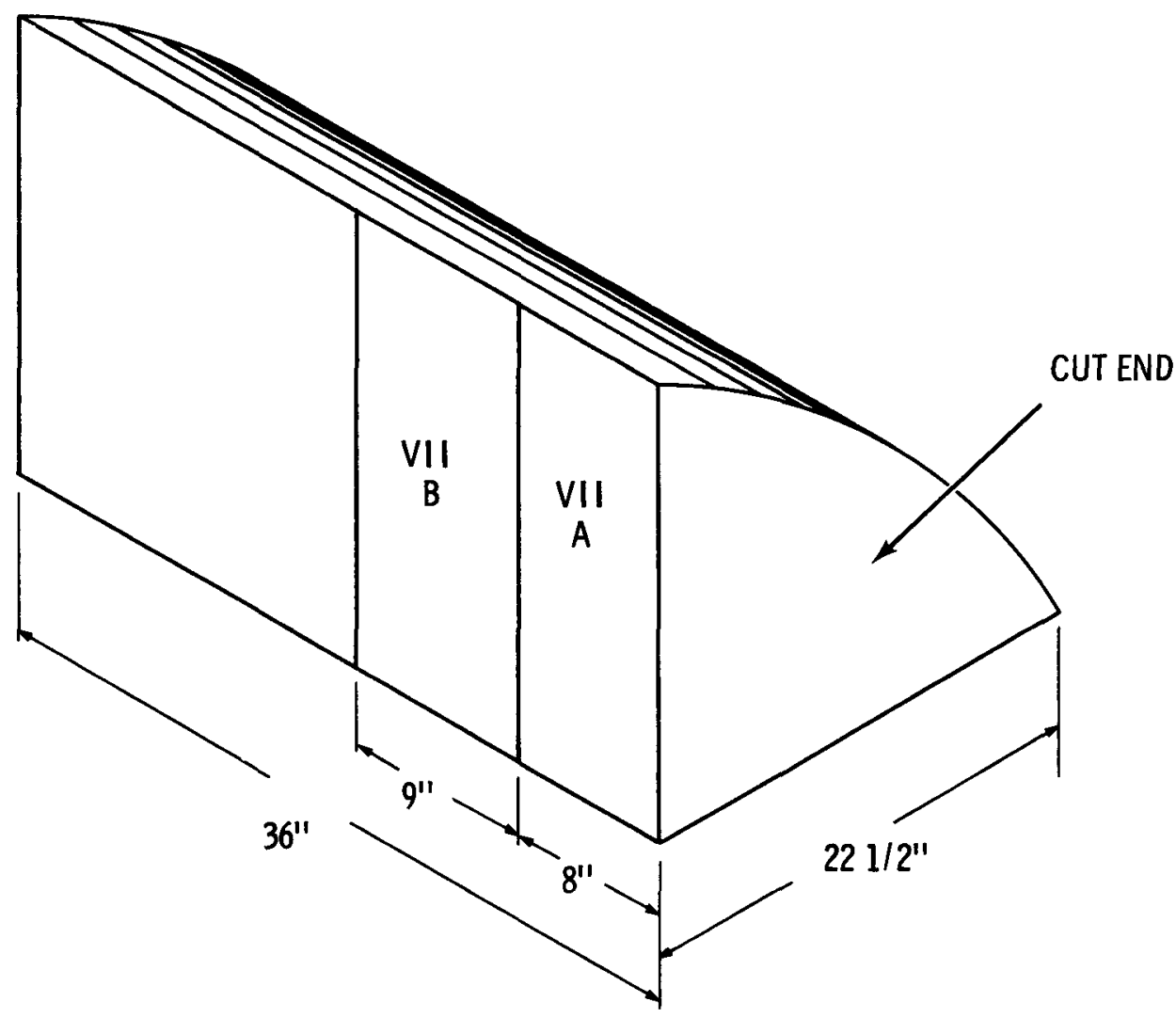

FIGURE A.1. Perspective View of the Log Section 

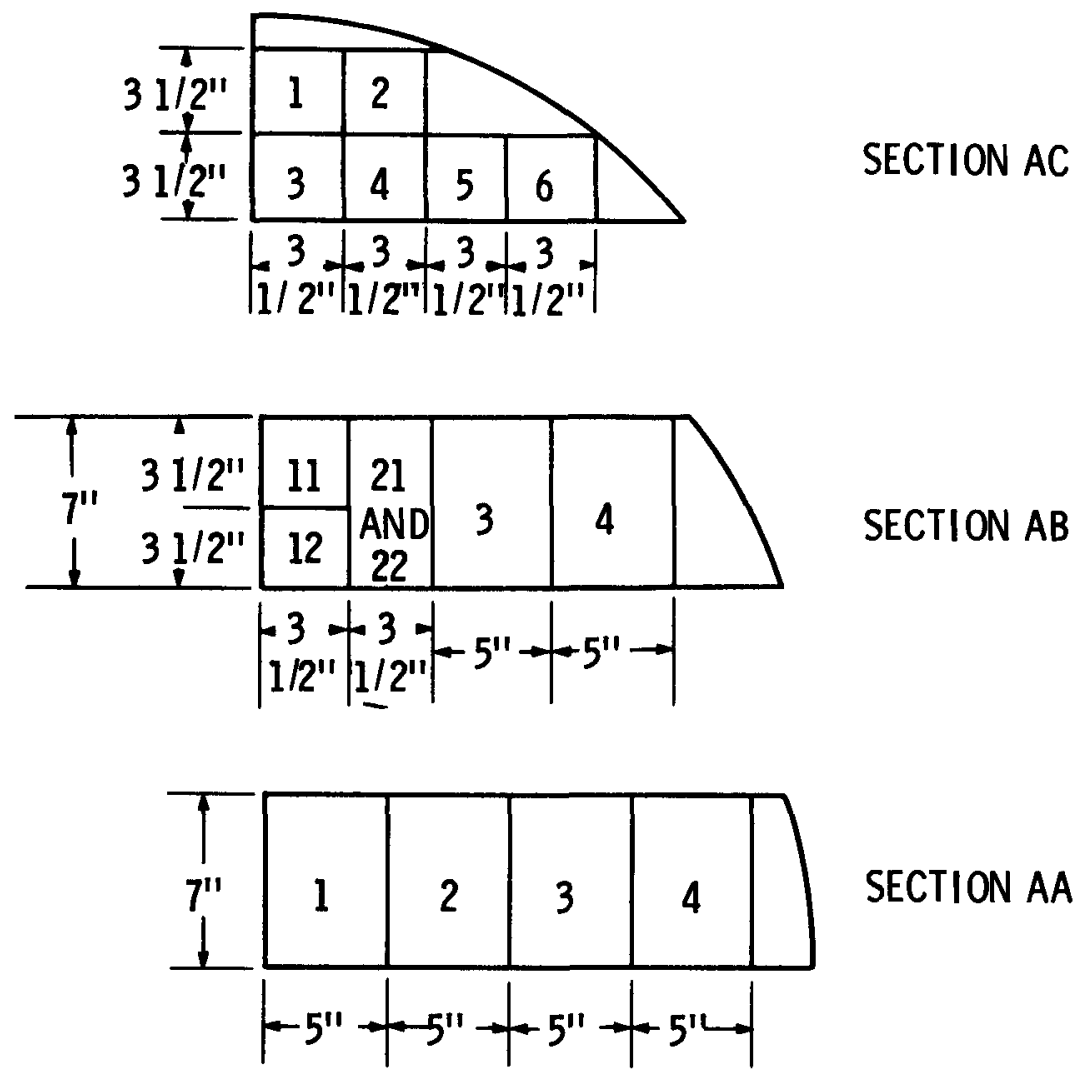

FIGURE A.2. Sampling Scheme of Section A 


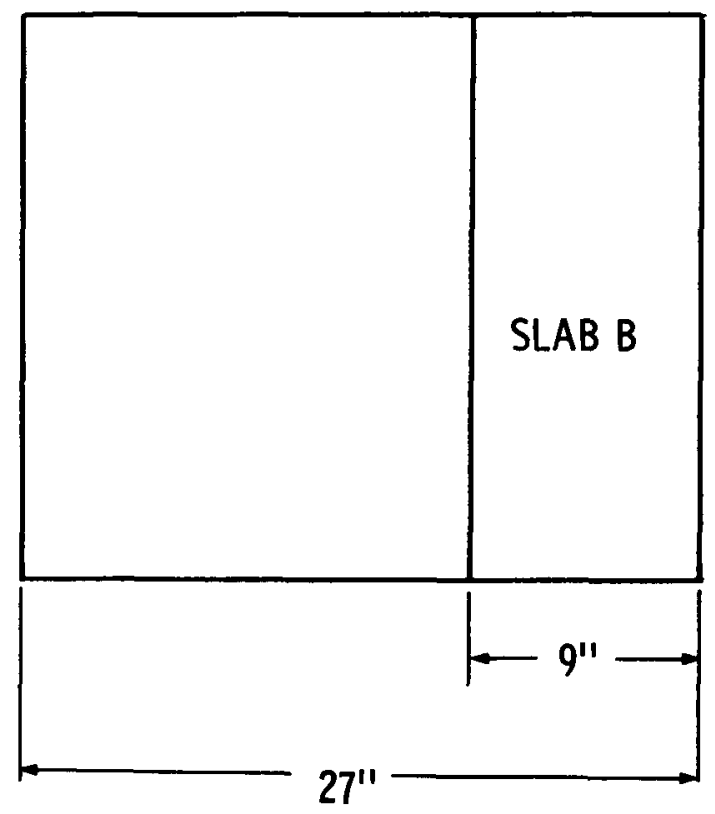

SIDE VIEW

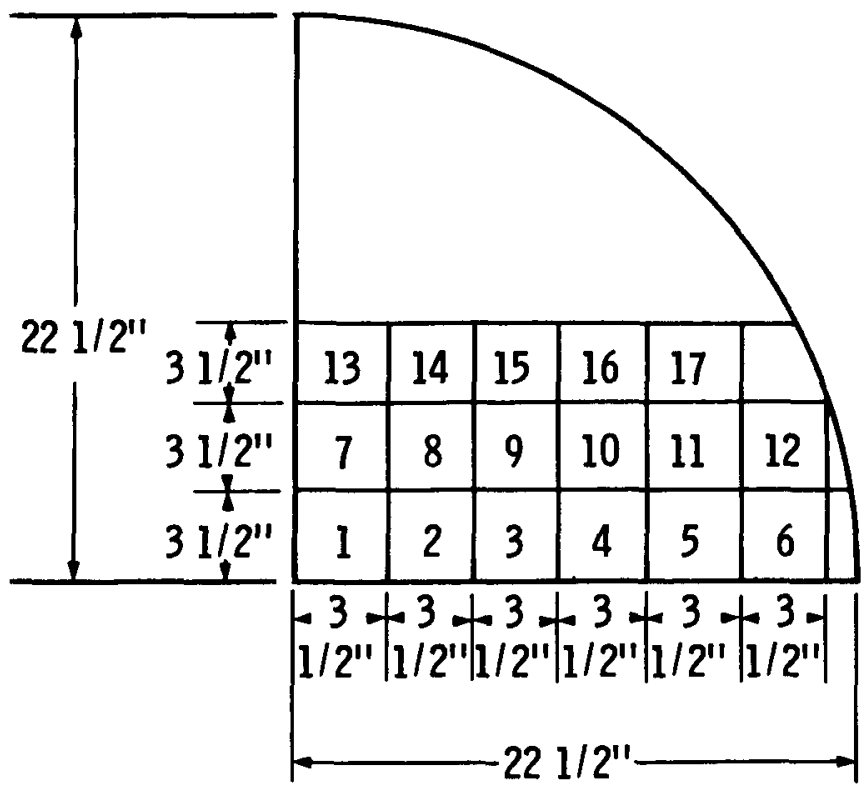

END VIEW

FIGURE A.3. Sampling Scheme of Section B 
TABLE A-1. Notes on Sample Preparation

Samp le

No. Notes

$A B-11$

$A B-22$

$A C-1$

$A C-2$

$A C-3$

AC-4

$A C-5$

$A C-6$

$B A-2$

$B A-4$

BA-6

BA-7

BA-15

BA-17

Machined into cylinders, $76 \mathrm{~mm}$ ( $3 \mathrm{in.}$ ) in dia by $156 \mathrm{~mm}$ ( $6 \mathrm{in.}$ ) long for measurements (including strength) of the unoxidized material.

BA-1

$B A-3$

$B A-5$

$B A-8$

BA-9

$B A-10$

BA-11

$B A-12$

BA-14

BA-16

Machined into cylinders, $76 \mathrm{~mm}$ ( 3 in.) in dia by $203 \mathrm{~mm}$ ( 8 in.) long for pre- and post-oxidation measurements.

AA-1

$A A-2$

AA-3

$A A-4$

$A B-3$

$A B-4$

$A B-12$ Sliced and machined into plates $1.25 \mathrm{~mm}(0.050 \mathrm{in.})$ thick by $A B-21 \quad 76 \mathrm{~mm}$ ( 3 in.) square. The surface of the plates from $A B-12$ is transverse to the long axis of the parent log; those from $A B-21$ are parallel to the long axis. 
APPENDIX B

NOTES ON OXIDATION RATE 


\section{NOTES ON OXIDATION RATE}

During the oxidation runs, it was found to be advantageous to plot the weight loss against time-at-temperature on a $\log -\log p l o t$, as shown Figure B.1. Once a slope was established for a given sample, the length of time required to reach a given weight loss could be easily predicted by extrapolation of the line. This correlation is based on the assumption that the equation for weight loss $(\Delta W)$ is related to oxidation time as given in Equation B. 1 .

$$
\Delta W=K t^{\beta}
$$

Where $K$ can be thought of as a temperature-dependent reactivity term, and $B$ accounts for the increased accessibility of the oxidant with burn-off. In our previous investigations, (Morgan and Becker 1977, 1979) differences of 2 to $3 x$ in oxidation rates have normally been observed for $3-i n$. dia samples of other graphites cut from the one log and oxidized adjacent to each other in the furnace. Thus, $K$ must be determined for each sample; this requires that $\Delta W$ be obtained at two different times $\left(t_{1}\right.$ and $\left.t_{2}\right)$. Moreover, if the difference between $t_{1}$ and $t_{2}$ (or $\Delta W_{1}$ and $\Delta W_{2}$ ) is smal1, little confidence can be placed on the calculated values of $\beta$ or $K$; therefore, we have not included three samples in Table B.1 (the largest difference $\Delta W_{2}-\Delta W_{1}$ was $3.3 \%$, and the largest difference $t_{2}-t_{1}$ was $8.3 \%$, for these samples). The values of $B$ and $K$, calculated for the other 7 samples, are listed in Table B.1

The data, at 1.2 and $10.5 \%$ weight loss, from $B$ lock $A A-4$ yields $\beta=1.56$ and $K=0.047$ for the oxidation at $875^{\circ} \mathrm{C}$. Using the average value of $\beta=1.53$, the data for the blocks oxidized at the higher temperatures was extrapolated to $10 \%$ weight loss. An Arrhenius plot of the relative weight loss rate versus inverse temperature, Figure B.2, yields an activation energy of $306 \mathrm{~kJ}$ per mole-degree (73.2 $\mathrm{kcal} /$ mole-degree) for the $\mathrm{CO}_{2}-\mathrm{C}$ reaction for these samples.

This activation energy is considerably larger than the $229 \pm 10 \mathrm{~kJ} / \mathrm{mole}$ degree reported by Eto and Growcock (1981) for samples of PGX oxidized in $2 \%$ $\mathrm{CO}_{2}$ at slightly lower temperatures, but both activation energies are we 11 within the range of activation energies reported by Walker et al. (1968) for graphites doped with $\mathrm{Fe}, \mathrm{Co}$, or $\mathrm{Ni}$ and oxidized in pure $\mathrm{CO}_{2}$ over approximately the same temperature range which we used for the blocks. 


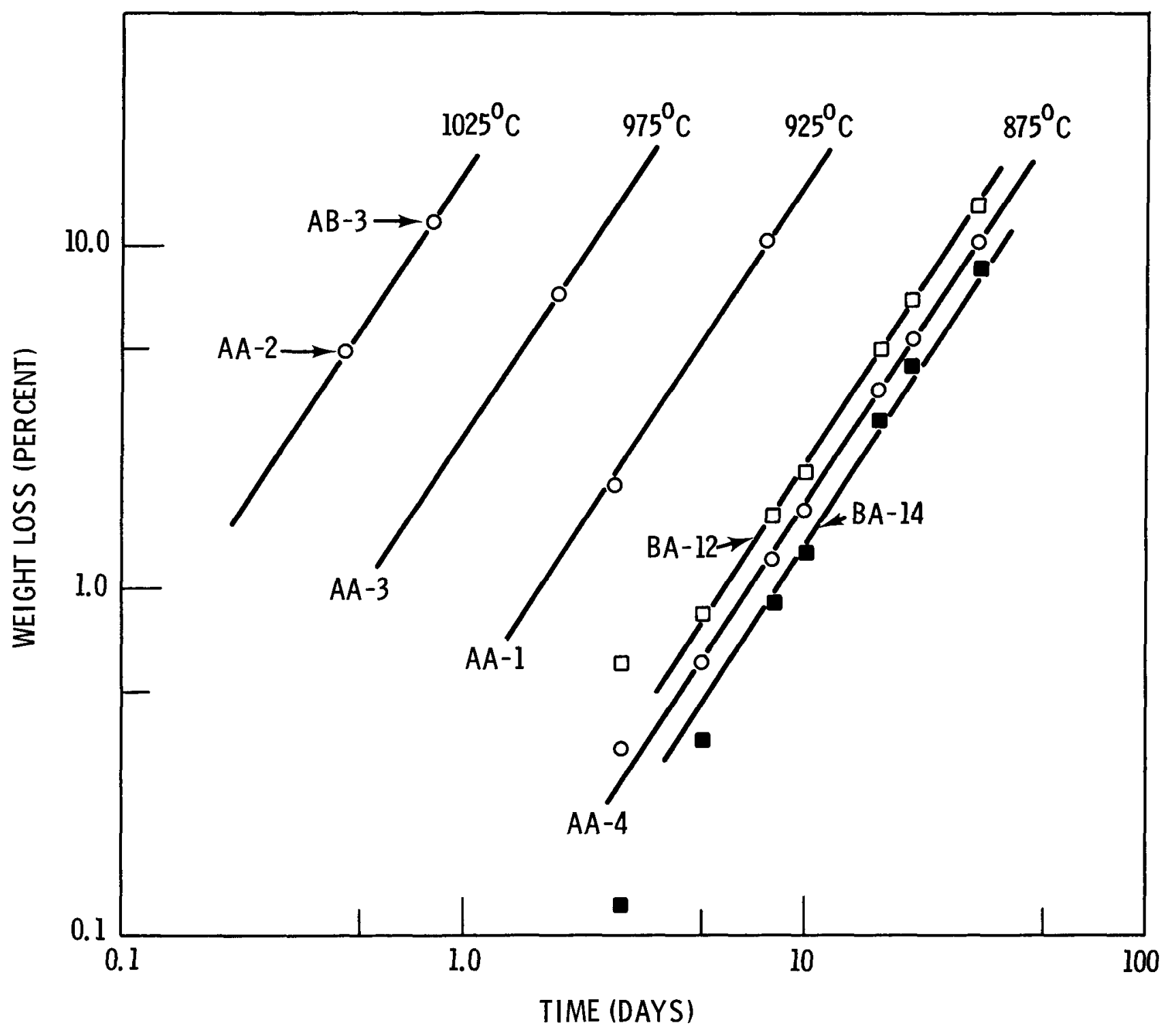

FIGURE B.1. Weight Loss and Function of Time-at-Temperature 
TABLE B.1. Calculated Rate Constants

\begin{tabular}{|c|c|c|c|c|c|c|c|c|}
\hline \multirow{2}{*}{$\begin{array}{c}\text { Sample } \\
\text { No. } \\
\end{array}$} & \multicolumn{3}{|c|}{ Weight Loss, $\%$} & \multicolumn{3}{|c|}{$\begin{array}{l}\text { Time at } \\
\text { Temperature, }\end{array}$} & \multicolumn{2}{|c|}{$\frac{\text { Rate Constant }}{(a)}$} \\
\hline & $\Delta \mathrm{W}_{1-}$ & $\Delta_{2}$ & Diff. & $t_{1-}$ & $\mathrm{t}_{2-}$ & Diff. & $\beta$ & \\
\hline BA-1 & 1.0 & 6.8 & 5.8 & 8.0 & 32.2 & 24.2 & 1.38 & 0.056 \\
\hline BA-11 & 1.2 & 8.7 & 7.5 & 10.0 & 32.2 & 22.2 & 1.69 & 0.025 \\
\hline BA-10 & 1.2 & 9.5 & 8.3 & 8.0 & 32.2 & 24.2 & 1.49 & 0.054 \\
\hline BA-8 & 1.1 & 10.5 & 9.4 & 8.0 & 35.0 & 27.0 & 1.53 & 0.046 \\
\hline$B A-9(a)$ & 2.0 & 11.8 & 9.8 & 10.2 & 32.2 & 22.0 & 1.54 & 0.056 \\
\hline BA-14 & 1.3 & 12.6 & 11.3 & 10.0 & 42.2 & 32.2 & 1.58 & 0.034 \\
\hline BA-12 & 1.7 & 13.4 & 11.7 & 8.0 & 32.2 & 24.2 & 1.48 & 0.079 \\
\hline Average: & & & & & & & 1.53 & 0.050 \\
\hline
\end{tabular}

(a) Rate coefficient in percent/t 1.53 .

(b) Sample BA-9 was damaged during testing and does not appear in Tables 3 or 4 . 


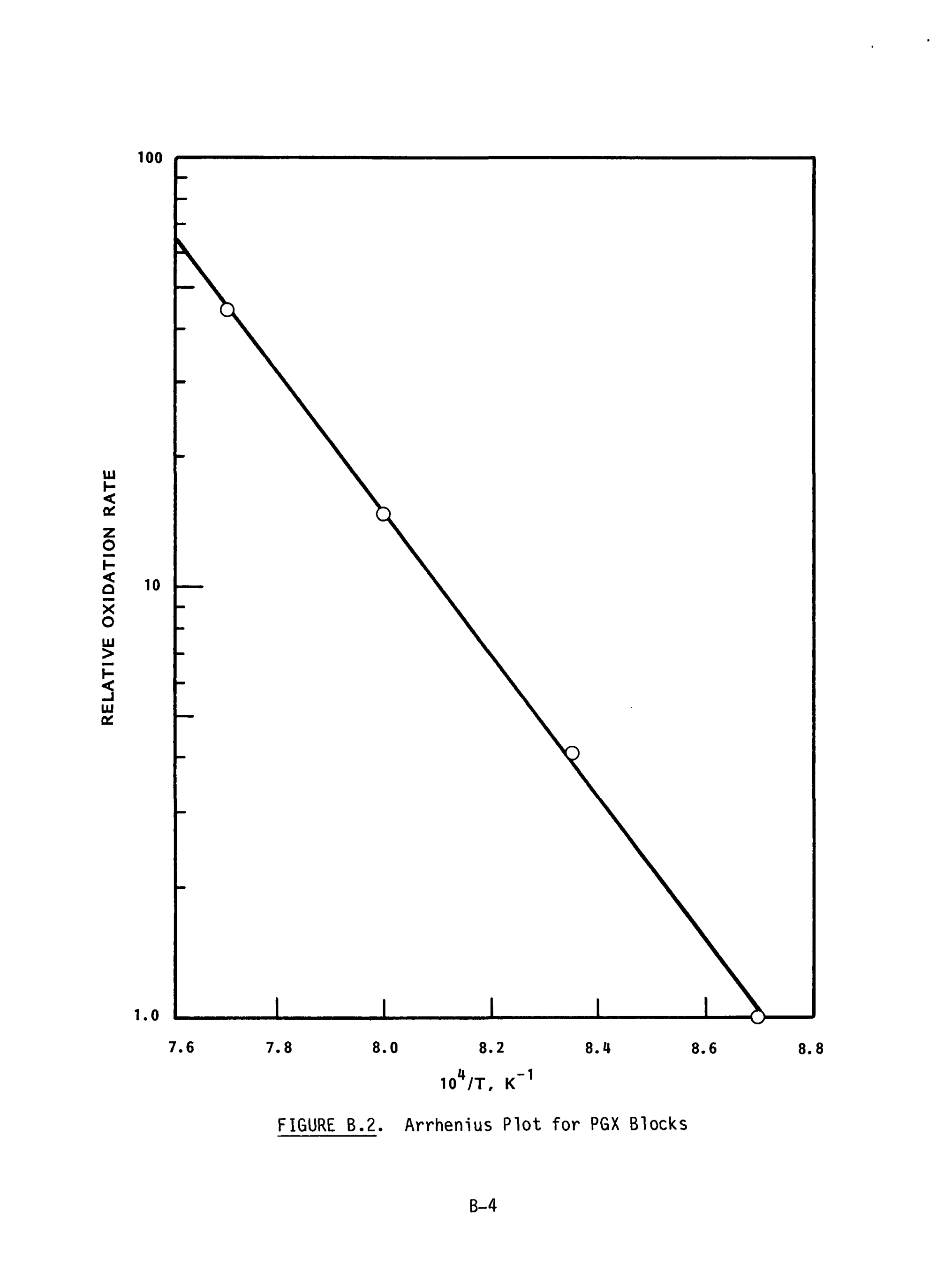




\section{DISTRIBUTION}

No. of

Copies

OFFSITE

255 Basic Distribution Under NRC R8

2 DOE Technical Information Center

R. A. Meyer

The Aerospace Corp.

P.0. Box 92957

Los Angeles, CA 90009

G. W. Morelli

Airco Carbon

800 Theresia St.

St. Marys, PA 15857

Carl Hastings

Army Materials \& Mechanics

Research Center

Watertown, MA 02172

S. Mrozowski

Ball State University

Department of Physics and Astronomy

Muncie, IN 47306

M. Eto

Brookhaven National Laboratory

Upton, NY 11973

C. A. Sastre

Brookhaven National Laboratory

Upton, NY 11973

Electric Power Research Institute Nuc lear Dept., Safety Analys is 3412 Hillview Ave.

P.0. Box 10412

Palo Alto, CA 94303
No. of

Copies

J. E. Fox

Department of Energy

Nuclear Research and Applications

Washington, DC 20545

H. L. Gotschall

Gas Cooled Reactor Associates

3344 N. Torrey Pines Ct., STE-300

La Jolla, CA 92037

F. E. Swart

Gas Cooled Reactor Associates

3344 N. Torrey Pines Ct., STE-300

La Jolla, CA 92037

A. W. Barsel 1

General Atomic Co.

P.0. Box 81608

San Diego, CA 92138

L. A. Beavan

General Atomic Co.

P.0. Box 81608

San Diego, CA 92138

R. D. Burnett

General Atomic Co.

P.0. Box 81608

San Diego, CA 92138

G. B. Engle

General Atomic Co.

P.0. Box 81608

San Diego, CA 92138 
No. of

Copies

T. D. Gulden

General Atomic Co.

P.0. Box 81608

San Diego, CA 92138

C. Velasquez

General Atomic Co.

P.0. Box 81608

San Diego, CA 92138

John Zebrick

General Electric AEG and Metallurgical Dept.

Evandale Plant

Cincinnati, $\mathrm{OH} \quad 45215$

L. A. Joo'

Great Lakes Research Corp.

Elizabethton, TN 37643

A. A. Cline

Great Lakes Carbon Corp.

Niagara Falls, NY 14302

I. W. Gazda

Great Lakes Carbon Corp.

Niagara Falls, NY 14302

R. C. Feber

Los Alamos Scientific Laboratory

P.0. Box 1663

Los Alamos, NM 87544

J. E. Foley

Los Alamos Scientific Laboratory

P.0. Box 1663

Los Alamos, NM 87544

W. L. Kirk

Los Alamos Scientific Laboratory

P.0. Box 1663

Los Alamos, NM 87544

T. C. Peng

McDonnell Douglas Research Laboratory

St. Louis, MO 63166
No. of

Copies

R. J. Edwards

Naval Surface Weapons Center

Silver Spring, MD 20910

R. A. Clark

Nuclear Regulatory Commission

Washington, DC 20555

R. P. Denise

Nuclear Regulatory Commission Washington, DC 20555

2 R. B. Foulds

Nuclear Regulatory Commission Washington, DC 20555

R. E. Ireland

Nuclear Regulatory Commission Washington, DC 20555

G. Kuzmycz

Nuclear Regulatory Commission Washington, DC 20555

G. W. Reinmuth

Nuclear Regulatory Commission Washington, DC 20555

D. F. Ross

Nuclear Regulatory Commission Washington, DC 20555

P. M. Williams

Nuc lear Regulatory Commission Washington, DC 20555

S. J. Ball

Oak Ridge National Laboratory

P.0. Box $X$

Oak Ridge, TN 37830

W. P. Eatherly

Oak Ridge National Laboratory

P.0. Box $X$

Oak Ridge, TN 37830 
No. of

Copies

A. P. Mal inauskas

Oak Ridge National Laboratory

P.0. Box $X$

Oak Ridge, TN 37830

R. P. Wichner

Oak Ridge National Laboratory

P.0. Box $X$

Oak Ridge, TN 37830

P. A. Thrower

Pennsylvania State University

Department of Materials Science

University Park, PA 16802

P. L. Walker, Jr.

Pennsylvania State University Department of Materials Science University Park, PA 16802

C. P. Murphree

POCO Graphite, Inc.

P.0. Box 2121

Decatur, TX 76234

J. L. Helm

Proto-Power Management Corp.

591 Toquonnock Road

Groton, CT 06430

L. Brey

Public Service of Colorado

Fort St. Vrain Nuc lear

Generating Station

406 Coffman

Longmont, CO 80501

J. Reesy

Public Service of Colorado

Fort St. Vrain Nuclear

Generating Station

406 Coffman

Longmont, CO 80501
No. of

Copies

R. R. Paxton

Pure Carbon Company

P.0. Box 386

St. Marys, PA 15857

D. W. Ballard

Sandia Laboratories

Albuquerque, NM 87115

H. S. Starrett

Southern Research Institute

Birmingham, AL 35205

W. A. Nystrom

Stackpole Carbon Company

Carbon Division

St. Marys, PA 15857

A. E. Goldman

Union Carbide Corporation

P.0. Box 6116

Cleveland, $\mathrm{OH} 44101$

D. B. Fischback

University of Washington

Dept. of Mining

Metallurgy and Ceramic

Engineering

Seattle, WA 98195

H. Burte

Wright Patterson

Air Force Base

Ohio 45433

\section{OVERSEAS}

R. L. Faircloth

AERE Harwell

Applied Chemistry Div. B10.5

Oxf ordshire, U.K. OX11 ORA

UNITED KINGDOM 
No. of

Copies
A. P. G. Rose
C.E.G.B., Berkeley Nuclear Laboratories
Berkeley
Gloucestershire GL 13 9PB
UNITED KINGDOM

W. J. Stephen

C.E.G.B., Berkeley Nuc lear Laboratories

Berkeley

Gloucestershire GL 13 9PB

UNITED KINGDOM

\author{
M. Yvars \\ C.E.N. de Saclay \\ B.P. No. 2 \\ 91190 Gif sur Yvette \\ FRANCE
}

Yasuichi Sasaki

Japan Atomic Energy Research Institute

Tokai-Mura, Ibaraki-ken

319-11

JAPAN

W. W. Delle

Kernforschungsanlage Julich

Postfach 365

5170 Julich

Federal Republic of Germany GERMANY

D. V. S. Revankar

National Chemical Laboratory

Chem. Eng. Div.

Pune 411008

INDIA

R. Blackstone

Netherlands Energy Research

Foundation

3, Westerduinweg

Petten; (NH)

THE NETHERLANDS
No. of

Copies

\author{
Jun-ichi Kon \\ Showa Denko K. K. \\ 6850, Omachi \\ Omachi-shi, Nagano-ken \\ T398 \\ JAPAN
}

S. Wilhelmi

Sigri Elektrographit GMBH Postfach 1160

8901 Meitingen bei Augsburg

WEST GERMANY

Hiroshige Suzuki

Tokyo Institute of Technology

12-1 0okayama 2, Meguro-ku

Tokyo

JAPAN

Laurenda Feneira

Universidade Nova de Lisbon

Faculdade de Ciencias

e Tecnologia

Quinta da Torre

2825 Monte da Caparica

PORTUGAL

S. Blairs

University of New South Wales

School of Met al lurgy

P.0. Box 1

Kensington N.S.W. 2033

AUSTRALIA

ONSITE

2 United Nuclear Industries, Inc.

D. H. Curtiss

J. P. Schmidt 
No. of

Copies

Pacific Northwest Laboratory

L. R. Bunnell

W. J. Gray

C. R. Hann

P. E. Hart

A. J. Haverfield

D. L. Lessor
No. of

Copies

W. C. Morgan (10)

G. J. Posakony

J. A. Prince

A. M. Sutey

M. T. Thomas (2)

G. L. Tingey

Technical Information (5)

Publishing Coordination $(K C)(2)$ 